\title{
Temas de Derecho Procesal (1)
}

\author{
Por el Dr. ERNESTO PERLA VELAOCHAGA *
}

\section{CONTESTACION A LA DEMANDA}

Esta etapa del juicio consiste en el acto del demandado de pronunciarse sobre la pretensión del acto.

Constituye asi un trámite esencial por razón del principio de contradicción que informa el proceso. Pero sólo exije que se cite al demandado y se le conceda la oportunidad de pronunciarse sobre la demanda y ponerse a derecho y no en que, efectivamente el demandado emplazado haga esta manifestación, pues puede no absolver el trámite, incurriendo entonces en la sanción legal de la rebeldía.

Por otra parte se ha hecho notar frecuentemente' 2 que no es propiamente una contestación porque ésta supone una interrogación y en la demanda el actor no interroga sino afirma. Pero quien hace la interrogación en la demanda no es el actor sino el Juez sobre la conformidad del demandado con los términos de la demanda y por esto es exactamente una respuesta o contestación.

IMPORTANCIA- - Esta proviene de los efectos que produce.- Sin salir de los limites de nuestro estudio para incursionar en el campo de la doctrina, la contestación de la demanda, tiene para el demandado los mismos efectos y trascendencia que la demanda tiene pasa el actor.

Ella prorroga la jurisdicción del Juez si no comprende la excepción declinatoria; después de la contestación no cabe la interposición de excepciones dilatorias ni la reconvención, ni variarse la demanda en lo sustancial; de su forma depende la tramitación posterior del juicio (allanamiento, que propiamente cierra la controversia, causa de puro derecho o juicio de prueba) y en fin señala y determinada el contenido de la controversia, y de la senten-

* Catedrático Titular de Derecho Civil (1er. Curso) y de Derecho Procesal Civil (20 Curso) en la Facultad de Derecho de la Universidad Católica.

1 Ver números XIX y XX de esta Revista.

2 Romero. - Ob. cit. T. II. pág. 34. 
cia. En una palabra determina la relación procesal y según sus términos se produce la controversia.

PLAZO.- Arts. 320 y 311 - El término para contestar la demanda del juicio que estudiamos es de 10 dias.-- Este es prorrogable conforme a los artículos 176-78 del C. de P.C. y las reglas que anteriormente han quedado expuestas.

Remitimos la cuestión a lo que ya se ha dicho sobre los términos y su cómputo. Sólo es preciso aclarar que se trata de un término individual y no perentorio esto es que, mientras no se acuse rebeldia puede absolverse el trámite aunque el plazo esté vencido.

Deben considerarse varios casos que alteran la regla general del Art. 320:

a) Caso de variación de la demanda.- Conforme la segunda parte del Art. 311 en caso de haberse variado la demanda, el plazo para contestarla corre a partir del traslado del escrito de alteración.

b) Caso del demandado que vive fuera del lugar del juicio.- Siguiendo las reglas generales, si el demandado no vive en el lugar del juicio, al término ordinario de 10 dias para contestar la demanda, hay que agregar el término de la distancia al lugar donde se encuertre el emplazado, según la tabla correspondiente de conformidad con los artículos 180 y 181 del C. de P. C.

c) Caso de haberse deducido excepciones dilatorias,- Siempre que se propone articulo de previo pronunciamiento, el plazo para contestar la demanda no corre sino cuando dicho artículo queda definitivamente resuelto. Como las excepciones dilatorias pueden subir hasta la Corte Suprema, sólo al bajar el expediente y a partir del día siguiente de la notificación del decreto "por devueltos" comienza correr el têrmino para contestar la demanda.

Se puede presentar el caso de que entre varios demandados, sólo algunos deduzcan excepciones dilatorias. Como el término, para contestar la demanda es individual, sólo para ellos el término queda suspendido mientras las excepciones se tramitan y resuelven. Para los demás codemandados que no han interpuesto las excepciones dilatorias, el término no se interrumpe. Sin embargo de que los demandados que no han interpuesto las excepciones dilatorias, están obligados a contestar la demanda, a su presentación debe darse por absuelto el trámite, pero reservar la prosecución de la instancia, hasta que sean resueltas definitivamente las excepciones planteadas.

Es necesario tener presente en cada caso la naturaleza de la cuestión previa propuesta. Distinguiendo aquellas que son previas a la sentencia, como la recusación o la acumulación, pero que no paralizan el juicio (Arts. 94 y 259 del C. de P.C.) ni causan tampoco el efecto de suspender el plazo para la contestación de la demanda.

d) Caso de devolución de la notificación de la demanda. - Es indudable que el término sólo corre a partir de las notificaciones válidas por estar hechas con todos los requisitos legales. Por esto en el caso del rubro la sus- 
pensión del término para contestar la demanda depende de lo que se resuelva sobre la validez de la notificación devuelta. Si se declara bien hecha la notificación ésta surte sus efectos desde que se hizo (Art. 159) y no desde el momento en que se desestimó la devolución.

REQUISITOS.- Art. 321.- De la misma manera que el Art. 306 preceptúa los requisitos formales de la demanda, este dispositivo señala los que debe contener la contestación a la misma indicando como tales:

1) La designación del Juez. - Nada es necesario agregar a lo que ya se expuso al respecto, pues la misma calidad y finalidad tiene que en la demanda.

2) Los nombres del demandante y demandado.- También se le aplican las reglas estudiadas al respecto en cuanto a la demanda.

3) La exposición de los hechos y de los fundamentos de derecho con que se contradice la acción, o el reconocimiento de su legalidad si se conviene en ella.

Este tercer inciso del Art. 321 se refiere al requisito de la exposición de hechos y de la fundamentación de derecho que también se han analizado; pero por supuesto, que esto no es necesario en ei caso de que el demandado convenga en la legalidad de la acción. Por eso que este punto nos lleva a tratar de los diversos modos de la contestación a la demanda.

MODALIDADES DE LA CONTESTACION A L A DEMANDAEs indudable que la contestación puede revestir diversas modalidades sobre todo si nos referimos a su contenido material. Pero ciñéndonos simplemente a las modalidades de orden procesal encontramos que la contestación puede ser: A) Expresa o real; B) Tácita o presunta.

A) Contestación expresa o real a la demanda es aquella en que el demandado absuelve el trámite. - El Art. 321. Inc. $3^{\circ}$ sólo señala dos posibilidades: contradicción o allanamiento. Pero al contestarse la demanda el demandado puede proceder en otras formas, nada lo prohibe'. Las modalidades principales que puede adoptar son las siguientes:

a) Allanándose. Art. 323, esto es contestando en forma afirmativa o sea conviniendo totalmente en la pretensión del actor.

Esta actitud del demandado se puede producir al contestar la demanda y también en cualquier otro momento del juicio, aunque nuestra ley no lo reconozca expresamente en este último caso. La diferencia está en cuanto a sus consecuencias económicas, pues en el caso de formularse al contestar la demanda, el demandado evidentemente que no queda responsable del pago de las costas; evidencia que no existe cuando el allanamiento se hace posteriormente a ese estado del juicio. 
Naturaleza.- El allanamiento constituye un acto de disposición o sea un acto con efecto inmediato sobre el derecho material ${ }^{1}$. En consecuencia sólo pueden ser materia de allanamiento los derechos disponibles.

$\mathrm{El}$ allanamiento tiene similitudes y diferencias con otros actos procesales especialmente con la confesión afirmativa. Essta última se refiere sólo a hechos, mientras que el allanamiento debe abarcar la admisibilidad de los hechos y del derecho alegado por el actor.

El allanamiento está sujeto a las siguientes reglas:

1) En cuanto a las personás que pueden convenir en la demanda: No existe dificultad cuando el propio demandado capaz se allana a la demanda. Pero cuando lo hace una persona en nombre y representación de otra deben distinguirse los requisitos que se exigen: a) al apoderado. No puede convenir en la demanda sino en el caso que se le haya concedido expresamente esta facultad (Art. 10) pues se trata de atribución comprendida entre las facultades especiales del mandado.- b) a los representantes legales de menores e incapaces (Art. 323). Sólo pueden allanarse, mejor dicho para que tengan eficacia su allanamiento, debe este allanamiento ser aprobado mediante las formalidades establecidas para la transacción relativa a bienes de menores e incapaces. Por esto es que el Art. 323 se remite al numeral 1716 del C. C. que hoy corresponde al Art. 1312 del Código vigente- - Estas formalidades son: dictámen de dos letrados y del Ministerio Fiscal, y en ciertos casos audiencia del Consejo de Familia.- El marido no puede convenir en la demanda sobre bienes de su cónyuge sino mediante autorización expresa de ésta, otorgada por escritura pública (Art. 21) - c ) a los representantes del Estado y de las corporaciones oficiales (Art. 324). Sólo pued'en allanarse mediante la aprobación expresa hecha por el Gobierno o la Corporación.

2) En cuanto al objeto: a) el allanamiento, tiene que ser total. Como ya se ha indicado tiene que abarcar el hecho y el derecho alegado por el demandante. El allanamiento sólo limitado a los hechos, produciria las causas de puro derecho, que sólo elimina la recepción de la causa a prueba, pero que no dá por terminada la controversia la que queda expedita para sentencia. Por otra parte el allanamiénto obliga necesariamente la decisión del Juez a favor del actor si se trata de bienes disponibles, lo que no sucede en las causas de puro derecho.

Por supuesto que esta regla no se refiere al caso de haberse planteado acumulativamente varias acciones, en cuyo caso, cabe el allanamiento respecto de unas acciones, y la contradicción a las demás pretensiones demandadas acumulativamente. Es claro que si el demandado no conveniese en todas las pretensiones del actor, tendria que tramitarse la contradicción y resolverse respecto a los puntos que no hayan sido matéria del allanamiento.

b) el allanamiento debe referirse a los derechos privados remunerables $^{2}$. Esto significa que el allanamiento no es suficiente para producir una

1 L. Prieto Castro. - Derecho Procesal Civil. T. I. pág. 248.

2 L. Prieto Castro. Derecho Procesal Civil. T. I. pág. 285. 
sentencia favorable cuando se trata de cuestiones de orden público o contra las buenas costumbres. Así las acciones sobre declaración de bien propio de uno de los cónyuges, cambio de nombre, divorcio, etc., no pueden ser declaradas fundadas por el simple mérito del allanamiento.

3) En cuanto a la forma: el allanamiento debe ser incondicional esto es que no se admite inmediatamente sino convenir en la demanda en forma absoluta. Sólo asi se permite la sentencia de conformidad con el allanamiento. En general todos los actos procesales son incondicionales o puros.

También es regla relativa a la forma, que debe legalizarse la firma del recurso de allanamiento antes de proveerse. Ya sabemos que la legalización de la firma consiste en la diligencia por la cual quien ha suscrito un recurso se' ratifica en su firma, ante el actuario de la causa. La ley procesal no la prescribe especialmente para el caso que estudiamos, pero constituye una práctica establecida para que, cuestión de tanta trascendencia, esté rodeada de la debida autenticidad.

Tramitación.-- Art. 322.- El allanamiento produce una sustanciación particular de la causa. Esta se reduce a la siguiente: a) Se expide el decreto de autos con citación para sentencia; b) Se expide ésta de conformidad con el allanamiento. La expedición de la sentencia es necesaria para que haya una ejecutoria que permita hacer valer compulsivamente el derecho, si fuera preciso. Sin embargo a veces no es suficiente el allanamiento para declararse fundada la demanda, tal el caso en que se trate de cuestiones de orden público.

II.- También se puede contestar la demanda ejecutando o cumpliendo la obligación. Es más que el allanamiento porque no se requiere en este caso que produzca una sentencia desde que se ha cumplido con la obligación demandada. Sólo procede seguir los trámites de ejecución de sentencia.

III.- Otra forma que puede revestir la contestación es no afirmando ni negando. El demandado puede simplemente contestar diciendo que queda sujeto a lo que pruebe el actor. Este temperamento se puede adoptar en los casos que se trate de demandas entabladas contra personas que no fueron las que contrajeron la obligación demandada, tal los que son demandados por una obligación que se atribuye a su causante.

IV.--Reconviniendo.-- Esta otra modalidad de la contestación a la demanda lleva a tratar de la reconvención, materia de los artículos 326 al 331 del C. de P.C.

Concepto. - La reconvención consiste en la acción que el demandiado deduce contra el actor al contestar le demanda y dentro del mismo juicio. Constituyé asi una demanda distinta que puede o no tener relación con la demanda del actor. - Caso de que habiendo $A$ demandado a $B$ para que le pague una suma de dinero, éste último $B$, al contestar la demanda, reconviene a A para que le suscriba una escritura pública.- Hay desde entonces acciones reciprocas entre el demandante y el demandado, que se van a tramitar conjuntamente y ser resueltas en la misma sentencia. 
Por lo tanto los caracteres que presenta copulativamente son: a) es una pretensión del demandado contra el actor, esto es una acción en forma que entabla al demandado contra el demandante, no es una excepción ni ningún otro medio de defensa, sino que con ella se persigue el reconocimiento de un derecho distinto del que ${ }^{1}$ invoca la demanda; b) és una acción deducida por el demandado ante el mismo Juez que lo emplazó ${ }^{2}$. Si fuera entablada antz distinto Juez, no existira reconvención. c) es deducida al contestarse la demanda ${ }^{3}$.

Respecto a la naturaleza de la reconvención se puede aclarar lo siguiente: 1) La reccnvención no es una excepción. Fsta es un medio de defensa contra la acción interpuesta: en cambio la reconvención no afecta a la acción interpuesta y el derecho demandado, es distinto de ella. No pretende alterar lo demandado sino es una declaración que no se refiere a lo demandado. 2) La reconvénción es distinta de la compensación ?. La última es un medio de extinguir la obligación demandada; la reconvención en general no pretende tal fin. Cuando se deduce compensación no hay juicio doble lo que si sucede en el caso de la reconvención. Como consecuencia no cabe interponer excépciones por el actor en cambio es posible la excepción a la reconvención y en caso de compensación el actor no resulta demandado o reconvenido y jamás podrá ser condenado. Sin embargo históricamente en ella tuvo su origen la reconvención y fue el Derecho Canónico el que la extendió a toda clase de casos, resultando una figura procesal autónoma. De allí que hay sistemas que sólo admiten la reconvención ligada a la demanda y exigen la conexión entre lo demandado y reconvenido, mientras que otros, como el nuestro la consideran sin otro lazo entre ambas, que el material de estar deducidas déntro de un mismo proceso. 3) La reconvención es distinta de la acumulación. Tanto de la de procesos porque no hay sino uno so'o f no se requiere la conexión entre las acciones, cuanto de la acumulación objetiva de acciones, porque aunque es verdad que hay por lo menos dos acciones en el mismo proceso, la demanda y la reconvención, no están deducidas por la misma persona ni al mismo tiempo, que son característiras de ia institución procesal de la acumulación. Para algunos tratadistas de la talla de Alsina, Calamandrei ${ }^{4}$, Martirolo ${ }^{5}$ y Alsina ${ }^{6}$, constituye una forma de acumulación, sin embargo las diferencias entre ambos son claras: además de las expuesias por que: a) la compensación es un modo de extinguir obligaciones y asi sólo se refiere a estos; la reconvención a cualquier clase de relaciones jurídicas. b) la compensación se puede deducir en toda clase de juicios, la reconvención no puede plantearse én los juicios ejecutivos. Ej.

Alsina.- Ob. cit. T. III. pág. 202.

Tiravantes. - Tratado. T. II. pág. 121.

Manresa.- Comentarios. T. III. pág. 105.

Calamandrei. - Instituciones. pág. 221.

Martirolo. - $\mathrm{Ob}$. cit. pág. 17.

- Alsina. - Ob. cit. T. II. pág. 201. 
la compensación sobre reconocer el crédito demandado; la reconvención no requiere esto y plantearse a la vez que se niega y contradice la demanda. Cuando las distancias eran grandes y difíciles entre las sedes de los juzgados, o los jueces no eran permanentes.

Fundamento. El fundamento de la reconvención se encontró antes en el propósito de facilitar el ejercicio de los derechos cuando las distancias eran grandes y dificiles entre las sedés de los Juzgados, o cuando los jueces no eran permanentes, hoy se encuentra en el principio de la economia procesal qué en este caso tiene aplicación permitiendo que los conflictos que reciprocamente deben esclarecerse judicialmente se tramiten conjuntamente en un mismo proceso. No se basa pues como la acumulación én la conexión de los litigios ni en la mejor administración de justicia.

Requisitos. A) En cuanto a la materia, hay tres cuestiones principales; a) la cuestión que propone averiguar si la materia de la reconvención debe o no tener alguna relación con la materia de la demanda. Hay dos sistemas principales al respecto: 1) El francés por el cual la reconvención debe provenir de la demanda o tener conexión de ella. Asi puede reconvenirse a quien exige el cumplimiento de un contrato $\mathrm{d} z$ compraventa para que este se rescinda, $o$ al que demanda el pago de una suma para que se declare nula la obligación. Estas limitaciones se atribuyen a hechos históricos ${ }^{1}$ e indudablemente que en cierta forma, equivale a confundir la reconvención con la compensación y con las excepciones, esto és, considerarla como un medio de defensa. No es este el carácter que tiene siempre. Aunque el derecho pretoriano pudo inventarla por razones de equidad y tener asi esta calidad, no es menos cierto que el derecho canónico ${ }^{2}$ desarrolló y amplió su concepto fundándola en razones de economía procesal, admitiendo la ventaja de que las personas que entre si tienen cuestiones reciprocas los ventilen dentro de un mismo proceso, con tal que sean de igual naturaleza, aunque el origen de ambas sea distinto y como consecuencia, aunque la demanda y la reconvención puedan no tener conexión entre si. 2) El español es el otro sistema según el cual la reconvención no requiere tener relación con la de. manda.

Nuestro sistema es el segundo, pues no se impone la condición de la conexidad entre la materia de la demanda y de la reconvención.

b) Se requiere que las materias de la demanda y de la reconvención sean de la misma naturaleza procesal. Esto es que no puede reconvenirse en pleitos de naturaleza civil por cuestiones que sean de naturaleza penal o de trabajo. También podria decirse que se requiere que estén sometidas a la misma competencia ratione materiae ${ }^{3}$. Esto además trae la exigéncia que tanto lo demandado como lo reconvenido estén sujetos al mismo procedimiento, salvo por razón de la cuantía (Art. 327).

1 Alsina. - Ob. cit. T. II. pág. 158.

2 Alsina. - Ob. cit. T. II. pág. 154.

s Alsina. - Ob. cit. T. II. pág. 156. 
c) También se requiere-que la materia de la reconvención se refiera a obligación que el demandado deduzca contra el actor; esto es que, no puede reconvenirse sino por un derecho que el demandado se atribuye ser titular de la obligación que imputa al demandante. Si el demandado litiga a nombre o en representación de otro no puede reconvenir por derecho propio ni a la inversa, si el actor litiga por medio de otra persona, no se le puede reconvenir por obligaciones que no se deduzcan contra él sino por las relativas a su representante.

En verdad sólo se trata de obligaciones que pertenezcan al demandado contra el actor en el momento en que se produzca la reconvención, aunque originariamente puede haber pertenécido a un tercero y aún haber sido adquirido con posterioridad a la demanda, el crédito por el que se conviene.

B) En cuanto a las personas, deben considerarse los requisitos para poder reconvenir y ser reconvenidos.

a) Pueden reconvenir, por si los que pueden comparecer en juicio sin representantes. Cuando son varios los demandados, litis consorcio pasivo, pueden reconvenir todos o solo alguno de ellos ${ }^{1}$ y no cabé restricción alguna conforme a nuestra legislación. Es una consecuencia necesaria de las reglas sobre comparecencia ante el Juez y no necesita aclaración. En cambio el apoderado sólo puede reconvenir en el caso de que no esté prohibido por su mandante de interponer demandas nuevas. Pero no requiere poder especial. Los representantes legales tienen dentro de sus atribuciones, por no existir prohibición, la facultad de reconvenir. Los representantes de ausentes deben sujetarse a las reglas ya establecidas sobre interposición de demandas nuevas.

b) Pueden ser reconvenidos todos los demandantes. Esto es obvio pero sirve para indicar que el traslado de la reconvención debe entenderse con el propio actor, aunque tenga apoderado en el juicio en que se deduce, si este apoderado no tiene poder especial para contestar demandas nuevas.

Es una aplicación del principio general del Art. 310. El reconvenido podrá o no ampliar el poder conferido después de haber sido emplazado.

Tramitación. - La sustanciación de la reconvención se reduce a las siguientes etapas: 1) Interposición. - Se debe interponer en el escrito de contestación a la demanda. Asi pues el mismo término señalado para absolver este trámite rige para ejercer la facultad de reconvenir-- 2) Se confiere traslado al demandante por seis días (Art. 329).- Ya nos hemos referido a que este trámite debe notificarse con los requisitos del Art. 310 del C. de P.C. El término que se señala es inferior al que se otorga para contestar la demanda, a pesar de que la reconvención constituye una demanda nueva. No es un término prorrogable. Así como el término para contestar la demanda, no es perentorio.

El recónvenido puede proceder en estas formas:

1 Alsina. - Ob. cit. T. II. pág. 161. 
a) Allanarse a la reconvención, en cuyo caso reunidos los requisitos para que surta efectos el allanamiento, se reserva para ser sentenciada conJuntamente con la demanda.

b) Interponer excepciones dilatorias contra la reconvención Art. 330.Esta facultad está sujeta a las reglas siguientes: 1) Las excepciones deben deducirse dentro del sexto día, esto es, dentro del mismo término de contestarla.-2) Puede hacerse uso de todas las excepciones del Art. 312, salvo la de incompetencia, Art. 330, segunda parte. En el capitulo anterior hemos opinado que o se le dá a esta prohibición una interpretación amplia y entonces es peligroso e inadmisible el principio; o se le limita a que no puede objetarse la competencia solo por razón de la cuantía, lo que resultaria ocioso desde que existen los artículos 327 y 301 del C. de P.C.- 3) De las excepciones se corre traslado al reconveniente por tres dias, siguiéndose la tramitación general de las excepcionés dilatorias; pero corriendo ella en este paso en cuerda separado. Si esto significara que el procedimiento principal continúa, no tendrían el carácter de excepciones dilatorias a pesar dé la denominación que le dá el Código. 4) Se resuelven estas excepciones por cuerda separada siendo susceptible la resolución que se expida de los recursos de apelación y nulidad. Claro que por su carácter la tramitación del juicio queda suspendida durante la sustanciación de las excepciones (Art. 330).

c) El reconvenido contesta la reconvención sin deducir excepciones o sólo interponiéndolas con el carácter de perentorias. En este caso con la absolución del trámite se recibe la causa a prueba, si se trata de causa de prueba, esto es, se tramitan conjuntamente la demanda y la reconvención. Desde este momento ya no puede variarse la reconvención sino en lo accidental, aplicando las reglas y efectos de la contestación a la demanda.

d) El reconvenido a su vez deduce reconvención. - Teóricamente esto es admisible desde que cabe acumular varias acciones sin limite alguno laguno por razón dei número, pero está rechazado en la práctica por razón de evitar indefinidamente la dilación de los procesos y la confusión que puede producir el admitirlas sin limitación.

e) El reconvenido no contesta la reconvención.-- Art. 331.- En este caso se le acusa rebeldia a petición de parte, se dá por absuelto el trámite y se procede igualmente a abrir la causa a prueba. (Art. 325).

f) La reconvención se resuelve conjuntamente con la demanda en la sentencia. No cabe que terminen por desistimiento los juicios en que hay reconvención por aplicación del Art. 265 del C. de P.C. y la jurisprudencia establecida.

g) El demandado contesta contradiciendo la demanda, - Esta contradicción o disconformidad puede revestir a su vez dos modalidades; referirse al fundamento de derecho o a los fundamentos de hecho de la demanda. Los estudiaremos separadamente a continuación.

1) Contradiciendo únicamente los fundamentos de derecho.-- Prodúcese en este caso lo que se llama la causa de puro derecho. En ella el demandado ha contestado la demanda manifestando conformidad en cuanto a 
los hechos que se relacionan en la misma, contradiciendo el derecho.-- Supongamos la entre nosotros tan discutida cuestión relativa a la sucesión del cónyuge. Los hechos del entroncamiento y demás son admitidos por el actor y demandado pero puede haber discrepancia en cuanto al sentido o alcance mismo. En esta clase de juicios no hay hechos que probar de aquí que se mismo. En esta clase de juicio no hay hechos que probar de aqui que se llama causas de puro derecho en contraposición a las llamadas de prueba.

Tramitación.-- Las causas de puro derecho tienen una tramitación especial: 1) El Juez califica la causa como de puro derecho. Esto es si se trata o no de una causa de esta naturaleza. No siempre es fácil esta calificación por la generalmente intima relación entre los fundamentos de hecho y de derecho. Pero la regla es que cualquiera duda debe resolverse en el sentido de que la causa es de prueba.- Puede-presentarse igualmente el caso de que las partes estén de acuerdo en que se debe omitir la prueba en cuyo caso el Juez deberá tramitar la causa conforme a lo pedido por las partes ${ }^{1}$, siempre que efectivamente no haya hechos controvertidos porque la recepción a prueba es de orden público en este último cass.

2) El Juez confiere traslado al demandanie para que replique y conteste la reconvención, si la hay.- Art. 342.- El recurso de réplica es de naturaleza y finalidad semejante al alegato, en aquel se glosan los argumentos de derecho, mientras que en esto se trata particularmente del resultado de las probanzas actuadas.

Debemos notar que en esa misma oportunidad el demandante debe absolver ell trámite de la reconvención si se hubiere planteado. - Esto presenta dos problemas: a) Si la reconvención es contestada en forma contradictoria sólo respecto al derecho en que se funda, no hay ninguna dificultad: la demanda y la reconvención pueden tramitarse como causa de puro derecho.b) Si la contradicción a la reconvención comprende también a los hechos ya la causa no puede tramitarse omitiendo la recepción a prueba. - En este segundo caso ya no debe absolverse el trámite de la réplica que en nuestra legislación es propia y exclusiva de las causas de puro derecho.

3) El actor debe absolver el trámite de la réplica dentro de seis dias (Art. 332). Este término es prorrogable conforme al Art. 176 del C. de P.C. Este trámite es renunciable según lo afirma, con discutible redacción el Art. 334, en forma expresa o tácita. En esta última forma dejando vencer el término sin absolver el trámite.

4) De la réplica se corre trasladó al demandado para que duplique.El trámite de duplicar tiene la naturaleza y está sujeto a igual término y reglas que el de replicar.

Respecto a los recursos de réplica y dúplica hay 3 sistemas: a) el que los establece para toda clase de juicios; b) el que los desconoce; y c) el que sólo los preceptúa para las causas de puro derecho. Entre nosotros se ha adoptado sucesivamente todos estos sistemas, pero actualmente el siste-

1 Romero. - Ob. cit. pág. 195. 
ma es el último, pues sólo se prescribe para las causas de puro derecho. Sin embargo, es evidente su inutilidad. Desde que las partes pueden hacer dentro de cualquier tiempo alegaciones y objecciones a lo expuesto por el contrario, nada justifica que se señale una etapa especial fara ejercitar esta facultad.

5) Se expide el decreto de autos con citación para sentencia, Art. 333 , una vez que se haya absuelto el trámite de la dúplica o vencido el término para hacerlo. Desde entonces queda la causa expedita para ser sentenciada.

2.- Contradiciendo los hechos.- En este caso el juicio se abre prueba. Es una consecuencia de que no estando las partes litigantes conformes respecto a todos los hechos es preciso pasar a la etapa de la instrucción para que se pueda comprobar o desmentir la efectividad de los mismos. Basta que haya algún hecho controvertido, aunque se hayan admitido como ciertos lo demás, para que proceda la recepción a prueba como trámite esencial. Es claro que la prueba sólo se refiere a los hechos negados por el demandado.

Se discute sobre si pueden darse como aceptados los hechos no expresamente contradichos por el demandado.

Las opiniones al respecto se dividen entre las que sostienen que deben contradecirse cada uno de los hechos y no admitir una negativa general. La sanción en caso de omitir la contradicción particularmente a cada hecho sería tener por ciertos los hechos no expresamente contradichos. Dentro de nuestro sistema el silencio no constituye manifestación de voluntad. Aún procesalmente no se ha adoptado el régimen de que el que calla otorga, salvo en casos muy excepcionales especificamente establecidos en la ley, imponiendo la obligación de pronunciarse bajo esta sanción. Asi en el caso de inasistencia del demandado al comparendo en el juicio de desahucio (Art. 957 del C. de P.C.), del confesante que no cumple con concurrir a absolver el interrogatorio después de la citación bajo apercibimiento, en el juicio de cuentas respecto a la partida no tachada exprzsamente. Pero en general el silencio no tiene el efecto de considerar que el demandado reconoce la efectividad de los hechos afirmados por el actor.- Aplicando estas reglas, en nuestra legislación, el demandado no está incurso en sanción por no contradecir expresamente cada uno de los fundamentos de hecho de la demanda. Se admite que puede negarlos y contradecirlos en forma general. Pero sí debe hacerse notar que si la contestación no sólo contradice sino que hace por su parte afirmaciones estas deberá probarlas oportunamente el demandado. Estas diversas actitudes del demaridado influyen en la prueba: si ha negado simplemente los hechos la carga de ella recae sobre el actor; si ha afirmado que la obligación existió y se ha extinguido, por pago, compensación, etc., en puridad de verdad está interponiendo excepciones perentorias cuyos fundamentos debe acreditar.

La posición contradictoria del demandado respecto a los hechos produce los llamados juicios de prueba. En forma especial constituye el juicio que estamos estudiando, el que se sigue por los trámites que expresamos anteriormente y las etapas del juicio ordinario que aún debemos estudiar. 
B) Contestación a la demanda tácita o presunta.- Art. 325.- Esta se produce con el silencio del demandado consistente en no contestar la demanda por lo cual, incurre, a pedido de parte, en rebeldia.

Debemos ir al Art. 193 y sgtes, del C. de P.C., para estudiar la rebeldia.

Concepto.- Art. 192 y 193.- La rebeldia constituye una sanción legal impuesta a quién omitió cumplir un mandato judicial, a absolver oportunamente un trámite o fue remiso a la concurrencia a una diligencia judicial. Como consecuencia se dá como practicada la actuación o absuelto el trámite en forma que coloca al rebelde en situación desfavorable dentro del juicio. Asi resulta que por razón de la rebeldía proceden sanciones diversas según se trate de sancionar la falta de manifestación a que estaba obligado alguien o de practicar otro acto judicial tal como la confesión, el reconocimiento o exhibición, Arts. 337, 428 y 447.- En el primer caso la sanción consiste en haber por absuelto el trámite y continuar el juicio sin oir al rebelde. En los otros casos, en presumir su conformidad con lo afirmado por el contrario.

Esto es que tratándose de la absolución del trámite de contestación a la demanda produce el efecto principal aunque no exclusivo. de haberla por contestada.

La rebeldia es distinta de la contumacia,- Esta última supone que se requiera al demandado para que absuelva el trámite de contestación a la demanda bajo el apercibimiento de ser declarado contumaz. Todavia posteriormente debe deciararse consentida la contumacia y sólo entonces se produce el estado de rebeldia.- Este es el procedimiento ordinario de los juicios ante el Juzgado de Paz. Pero ha desaparecito la contumacia en el juicio ordinario que estamos estudiando.

Como la contestación a la demanda es tráaite no perentorio, el demandado puede absolver el traslado de la demanda y librarse de la situación de rebelde mientras no se le haýa acusado rebeldia, aún después de vencido el término de ley. Así pues, vencimiento y acuse de rebeldía son las dos condiciones para que se considere producida la contestación presunta.

Debe diferenciarse tambièn la rebeldia del apercibimiento y del apremio. Esto nos lleva al título VIII del C. de P.C. Apercibimiento es el requerimiento para que se cumpla un mandato judicial bajo la amenaza de una determinada sanción. El apercibimiento sólo se dicta en los casos que la ley determina. El apremio es la sanción. La rebeldía es una situación especial dentro del proceso, el estado de rebeldia puede no proceder de un apercibimiento o requerimiento previo.

Se diferencia también del apremio en que este es un medio de constreñiı a ejecutar algo dentro del proceso como acudir al Juzgado, exhibir un documento $u$ objeto, devolver unos autos, etc; mientras que la rebeldia es la situación en que ya se ha colocado una persona dentro del proceso.

Apremio y rebeldia se distinguen por sus efectos, pues el primero generalmente produce la ejecución a fortiori del acto omitido, embargo para el pago de una obligación, allanamiento de domicilio, para la entrega o exhibi- 
ción de cosas o instrumentos, conducción del testigo por la fuerza al local del Juzgado, etc.- La rebeldía no produce efecto sino de carácter legal como es colocar a la persona rebelde en determinada situación dentro del proceso, cual es la que indicamos a continuación.

Forma. - La rebeldía: 1) sólo puede ser decretada a pedido de parte, no de oficio. según el Art. 197. salvo que el Juez ejerza facultades inquisitivas como en los casos de los artículos 374 y 428 . Esto se explica por el carácter de nuestro procedimiento y por la finalidad de la misma. que el juicio, continúe.- 2) Se puede acusar verbalmente: Art. 198.- Disposición fundada en ei propósito de aligerar los trámites. pero que supone se haga constar por acta.- Por supuesto que también se puede formular por escrito, siendo esta la forma usual de solicitarla.

Efecto de la rebeldia.-- Como constituye la rebeldía una sanción legal contra el omiso a la absolución de un trámite obligatorio dentro del proceso, y asi al de la contestación de la demanda, por ello se coloca al rebelde dentro de una situación especial y desfavorable dentro del juicio.

Los efectos principales que produce son: 1) En cuanto al trámite omitido, se da por absuelto, Art. 192. Esto es que se tiene en el caso que tratamos, por contestada la demanda. No produce entre nosotros y en el juicio ordinario, el efecto de tener por ciertos y consentidos los hechos en que se funda la demanda. Ya se ha indicado cual es el valor del silencio en el Código Procesal y como este efecto sólo se produce excepcionalmente en los juicios de desahucio o de cuentas por disposición expresa de la ley ${ }^{1}$. Dentro del juicio ordinario por falta de contestación expresa a la demanda la rebeldía solamente produce el efecto de dar por absuelto el trámite. Esto está justificado por efecto de que sino el procedimiento se estancaria por voluntad irremovible del demandado. Al tenerse por absuelto dicho trámite se suponen verificados todos los efectos de la contestación a la demanda que anteriormente hemos expuesto.

Hay que dilucidar si la caducidad del término para el trámite no absuelto se produce al presentarse el acusé de rebeldia o con la resolución del Juez que defiriendo al pedido del interesado declara rebelde al omiso ${ }^{2}$. Esta es una cuestión con frecuencia general que vamos a aplicarla al caso de la contestación a la demanda. El caso puede revestir estas circunstancias: 1) El plazo de contestación ordinaria o prorrogado se vence sin que se haya absuelto el trámite y $\sin$ acusarse rebeldía; el demandado puede absolver el trámite, porque no es un término perentorio.- 2) El plazo está vencido y se acusa rebeldia al mismo tiempo que se absuelve el trámite de tal manera que los dos recursos llegan conjuntamente al Juez. La cuestión estriba en saber cuál tiene preferencia: unas opiniones sostienen que aunque no está decretada la rebeldía, desde el momento que está acusada y que el Juez no puede denegarla por haberse vencido el término, ya no puede admitir la

1 Arts. 956 y 510 del C. P. C.

2 Couture.- Fundamentos, pág. 114. 
absolución del trámite; otras que, como la rebeldia no tiene otro fin que hacer prosperar el procedimiento, conseguida esta finalidad con la absolu ción del trámite, no cabe decretarse la rebeldia.

Como muy bien lo indica el profesat Couture, la doctrina está a favor de la primera solución y la jurisprudencia, con su sentido a favor de la amplitud de la defensa, se pronuncia por la segunda.

Entre nosotros igualmente se aplica el segundo sistema; es posible absolver el trámite mientras no se encuentre decretada la rebeldía aunque ya esté acusada. Tratándose de cualquier otro caso distinto de la contestación de la demanda debe tenerse en consideración si se trata de término perentorio o no perentorio. En el primer caso se aplica la solución indicada y en el segundo, no por la rebeldía, sino por la calidad del término, no puede absolverse extemporáneamente el trámite, aunque la rebeldia ni siquiera esté acusada.

2.- En cuanto a los términos corren contra el rebelde como si litigase personalmente (Art. 194).

La ley quiere decir con ésto que los términos le corren como si se hubiese presentado. Esto es efecto natural del acuse de rebeldía.

3.- En cuanto a las notificaciones se tendrá al rebelde por notificado de las providencias el mismo dia que se expidan, salvo de las que deben notificársele conforme al C. del P.C. (Art. 194). Esto significaba en el procedimiento del Código de Enjuiciamientos "La notificación, con los estra. dos". según lo recuerda la Exposición de Motivos del C. de P.C. vigente. En este caso ya no es necesaria la notificación por cédula ni en ninguna otra de las formas establecidas, sino que el rebelde debe ir a la oficina del actuario para conocer de las resoluciones judiciales que se expiden en el juicio.- Sin embargo éste régimen tiene excepciones, a ellas se refiere la última parte del Art. 194, y están establecidas en el Art. 325. Conforme a êste último precepto al rebelde se le debe notificar necesariamente estas resoluciones: en el juicio ordinario el auto que manda seguir el juicio en rebeldia; el que recibe la causa a prueba, sólo en lo principal; la citación para sentencia, la sentencia y auto en el que se le requiere para su cumplimiento. En el juicio ejecutivo sólo se notifican las resoluciones que se indican en el Art. 682. Todas se justifican por la trascendencia de las mismas resolucione.s

4.- Imposición de una multa (Art. 199). - Toda rebeldia lleva consigo la imposición de dos soles de multa.- Mientras no se cumpla con abonar ésta, que es lo que se llama purgar la rebeldia, el rebelde no puede ser oido en el juicio:

5. - El rebelde no puede salir a juicio sin purgar la rebeldia (Art. 200 y 196).- Purgar la rebeldia consiste en pagar la multa a que una persona se ha hecho acreedora. El importe de la multa es de dos soles. Sin embargo no todos los rebeldes llevan esta multa, sino que conjunta o separadamente hay otras sanciones para los casos de absolución de posiciones, reconocimiento de documentos y otros, según el Art. 193. Mientras tanto no se puede admitir al rebelde recurso alguno y si se le admitiera, a pedido de parte, 
puede declararse insusbsistente el proveido recaído en él y tenerse por no presentado el recurso. Esta situación se mantiene en el procedimiento de ejecución de sentencia.

6) El rebelde que purga la rebeldía seguirá el juicio en el estado en qu se encuentre'. (Art. 195). - Asi no se retrotraen los juicios, por el hecho de salir al juicio el rebelde, sino que avanzado el procedimiento, el rebelde lo sigue desde la estación en que se halle el pleito en el momento en que se apersona, abonando la multa correspondiente.- Se discute sin embargo sobre si el rebelde puede pedir la nulidad e insubsistencia de lo actuado durante el periodo de la rebeldia. Esto puede constituir una forma de retrotraer el juicio a un estado anterior. Entre nosotros la muy autorizada opi nión del Dr. Julián G. Romero, fundándose en la legislación española cree que es improcedente admitir el artículo de nulidad que deduzca el rebelde. Pero podria hacerse una distinción según el fundamento de la nulidad deducida. Si se fundara en causales que afectan el orden público y que aún dé oficio pueden decretarse, en los que no cabe la renuncia ni por la voluntad de las partes, podria admitirse, desde que la rebeldia tiene por fundamento el presunto abandono el juicio o el consentimiento del rebelde; tratándosé de actos que no pueden convalecer por la simple voluntad de las partes, la presunción, no podría funcionar, luego seria admisible el artículo de nulidad.

\section{VI.- PRUIEBA}

Importancia.- Siempre que el demandado contradice los fundamentos de hecho de la demanda, es preciso recibir la sausa a prueba. Esto porque las alegaciones que hacen las partes, teniendo personalmente el mismo va. lor, tienen que ser acreditadas a fin de que el Juez pueda pronunciar su decisión de conformidad con las comprobaciones verificadas dentro del juicio.

De aqui la importancia trascendental de esta etapa del juicio desde que de ella depende la suerte del pleito. la sentencia.

Concepto.- Varias definiciones se pueden proponer de la prueba: a) Desde el punto de vista común, es demostrar 0 acreditar la efectividad de un hecho.- b) Procesalmente, tiene a su vez dos acepciones: o bien es la demostración de la efectividad de los hechos controvertidos; o bien es el medio de que se puede valer las partes, para acreditar los hechos de los que hacen depender su derecho ${ }^{1}$ o pretensión.

No corresponde a los limites del presente estudio, referirnos a las múltiples cuestiones de orden doctrinario, que planea el concepto de prueba, sin duda uno de los que más ha sido materia de exégesis en la literatura tanto de derecho sustantivo como procesal. Remitiéndonos a dicho trabajos

1 Romero. - Ob. cit. T. Il. pág. 227. 
sobre el particular ${ }^{1}$ sólo nos referimos suscintamente' a aquellos conceptos necesarios de recordar, para mejor entender la tramitación del juicio ordinario en nuestra legislación, o objetivo de la presente exposición.

Para el objeto de nuestro estudio consideramos la prueba como la etapa del procedimiento dentro de la cual debe acreditarse, mediante los medios que la ley permite, los hechos alegados y controvertidos.

Explicando estos términos cabe notar que la prueba la consideramos así una etapa, esto es un período dentro del juicio que nos llevará a estudiar: 1) cuando procede esta etapa; 2) su objeto, esto es qué debe probarse; 3) carga de la prueba o quien debe probar; 4) su duración o sea el término probatorio; y 5) desde que este periodo tiene por fin que se actúen los medios comprobatorios que la ley permite, conducirá al estudio de cómo se debe probar o sea el examen a cada uno dé los medios prueba.

También queda indicado dentro de la definición que el objeto de la prueba es acreditar los hechos controvertidos, esto es que solo se debe referir a los hechos en que las partes no han convenido expresamente. $Y$ por último, que esta comprobación se debe hacer valiéndose únicamente de los medios que la ley permite.

I) Procedencia de la recepción a prueba - Art. 335 y 336.- La prueba tiene por finalidad acreditar los hechos en los que las partes no están conformes.

En consecuencia no procede la recepción a prueba cuando no hay hechos que probar: 1) en los casos de allanamiénto; desde que el demandado conviene en la integridad de la demanda; 2) en las causas de puro derecho, desde que el demandado no contradice tampoco en este caso los fundamentos de hecho de la demanda.

II) Obieto dro la prueba.- De lo expuesto se deduce lo que debe pro barse, cuyas reglas sè pueden sintetizar en las siguientes:

1) La prueba sólo se refiere a los hechos. - Art. 337.- El derecho que se invoca en juicio no se prueba sino excepcionalmente. El juez conoce el derecho del país donde ejerce el cargo. Unicrmente cuando se trata de leyes extranjeras cabe la prueba sobre la existencia y el alcance de las mismas, se consideran asi como hechos susceptibles de prueba, sin la cual el Juez no puede invocarlas al sentenciar.

Esta facultad está permitida expresamente por el Art. XII del Título Preliminar de nuestro Código Civil. No existe reglamentación especial sobre la forma de actuarla pero es de tener en consideración en estos casos la propuesta formulada por el Dr. Manuel Augusto Olaechea a la Comisión Reformadora. La forma de ejercitarla no puede ser otra sino que los jueces inferiores, si ellos son quienes o ante quienes se ejercita la facultad de probar la ley extranjera, lo hagan por conducto regular, esto es solicitando el informe por medio de la Corte Suprema, esta del Ministerio de Justicia y este que a su vez por el de RR. EE. al país de que se trata.

1 L. Prieto Castro. - Ob. cit. T. I. pág. 298. 
No habría inconveniente y se hace en la práctica, el solicitar al respectivo representante diplomático o consular la constancia sobre la existencia de la ley extranjera y su sentido.

Tratándose de prueba de la ley de alguno de los países signatarios del Tratado de Montevideo (Art. $2^{\circ}$ del Protocolo Adicional), se supone que el Juez las conoce como si fueran leyes nacionales desde que se establece que las aplicará de oficio como las leyes propias, aunque sin perjuicio de probar respecto de ellas.

También queda indicado dentro de la definición que el objeto de la prueba es acreditar los hechos controvertidos, esto es que sólo se debe referir a los hechos en que las partes no han convenido expresamente. $Y$ por último, que esta comprobación se debe hacer valiéndose únicamente de los medios que la ley permite.

2) La prueba debe concretarse a los hechos aducidos en el juicio.Art. 339. - Esto constituye el requisito de la pertinencia. Cuando las pruebas se refieren a los hechos materia de la controversia, se trata de pruebas pertinentes. Al decir la controversia estamos refiriéndonos a los hechos controvertidos o sea los que no han sido aceptados como verdaderos por la parte a quien perjudican. Cuando no reúne este requisito, la prueba es impertinente.

La prueba impertinente es distinta de la prueba inadmisible y la prueba inútil. - a) La inadmisibilidad de la prueba depende de que no sea un medio permitido por la ley, lo que constituye el requisito de la legalidad al que luego nos referiremos. La ley puede no reconocer absolutamente ta! medio como medio probatorio en general, asi en nuestra legislación el examen de la sangre para pretender con él acreditar la filiación; y otras veces no se permite un medio determinado sólo en formá relativa, para demostrar ciertos actos, como la prueba testifical para acreditar un mutuo de más de 500.00 (Art. 158 del C. C.). En todos los actos jurídicos solemnes se requiere una determinada forma. - b) La inutilidad de la probanza es distinta de la impertinencia, como lo observa el profesor Manresa. Lo impertinente es inútil, pero lo inútil no siempre es impertinente. Lo inútil es lo que teniendo relación con la controversia no puede influir en la decisión. Asi ofrecer prueba de testigos para acreditar la existencia del contrato de mutuo cuyo cumplimiento estoy demandando, además de haber comprobado su existencia con el documento respectivo, nada podrá añadir a la comprobación de la existencia de tal contrato la declaración testifical y consecuen. temente será una prueba inútil, pero no impertinente porque se refiere a los hechos aducidos y controvertidos.

Estas distinciones entre pertinencia, inadmisibilidad e inutilidad de la prueba sirve para establecer las facultades del Juez en cada caso. El Juez tiene obligación de rechazar las pruebas inadmisibles. Puede también repeler las impertinentes. Esto último como un derecho potestativo, que debe ejercer con extrema prudencia, porque es difícil a veces determinar la impertinencia sin incurrir en un prejuzgamiento o sin proceder con una apre- 
ciación fragmentaria e incompleta de la cuestión planteada. Por esto es que generalmente entre nosotros se sostiene y admite, que sólo al sentenciar se determinará la pertinencia o impertinencia de las pruebas. Pero hay una conocida regla ${ }^{1}$ que permite decidir acertadamente sobre las pertinencias de las pruebas ofrecidas. Consiste en que el Juez suponga a priori actuada la prueba. Si su resultado ya sea positivo o negativo, puede influir en la decisión del pleito la prueba será pertinente, é impertinente en caso contrario.

Conforme a la última parte del Art. 339 el Juez podrá repeler las pruebas manifiestamente impertinentes. Esto no sólo debe hacerlo en la sentencia, sino en el momento de su ofrecimiento, o por lo menos al ser objetadas como impertinentes, asi se sabrá exactamente sobre que elementos de prueba se va construir la sentencia.

Por último las pruebas inútiles, no pueden ser rechazadas por el Juez Está en el inzerés de las partes no recargar los juicios actuando probanzas que en nada han de variar la situación de quien la ofrece dentro del juicio y aún puede ser y és motivo muchas veces de maliciosas dilaciones, pero reuniendo el requisito de la pertinencia no pueden ser denegadas por el Juez.

3) La prueba sólo se refiere a los hechos controvertidos, esto es a los hechos en los que no han convenido expresamente la parte a quien perjudican. - Art. 339.

Debe notarse que se consideran hechos controvertidos todos los hechos rechazados como ciertos por el demandado o en general por aquella parts a quien perjudican. Nuevamente la regla de que no hay un reconocimiento simplemente tácito de los hechos ${ }^{2}$.

La justificación se encuentra en razones de orden lógico y práctico. $\mathrm{Sj}$ la prueba tiene por finalidad demostrar un hecho que perjudica a alguien $y$ si éste último está conforme con la efectividad del mismo hecho ya no es necesario que la prueba se produzca, o en cierta manera, el asentimiento del contrario ha demostrado su efectividad.

Por estos es que conforme ya se ha expresádo, la situación de rebeldia del demandado, debido a la cual nada ha admitido, no libera al actor de la obligación de probar los hechos en que se funda su demanda.

4) La prueba se refiere a los hechos que no se presumen conforme a la ley.- Art. 337.- Pertenece también al aspecto doctrinario la determinación del concepto de presunciones. Hay dos clases de presunciones: a) Pre. sunciones legaies son las establecidas en la ley. Consisten en aquellos hecho: que la ley da por probados. En este casu ha habido una operación previs y deductiva del legislador que del examen de caracteres comunes y normales de una circunstancia, deduce una consecuencia general. Asi los hijos de la mujer casada no separada del marido, tienen por padre a éste. De dicha observación obtiene la presunción respectiva; la regla que consagra el Art

1 Ricci. - Códice di Procediere Civite. T. II. pág. 4.

2 Alsina. - Ob. cit. T. II. pág. 533. 
$339 \mathrm{del} \mathrm{C.} \mathrm{C.} \mathrm{La} \mathrm{parte} \mathrm{al} \mathrm{afirmar} \mathrm{en} \mathrm{este} \mathrm{caso} \mathrm{la} \mathrm{filiación} \mathrm{legitima} \mathrm{no} \mathrm{tiene}$ sino que probar el hecho en que se funda la presunción; en el ejemplo propuesto, el matrimonio de los padres y prescinde de las demás pruebas del caso. Probado al matrimonio de los padres los hijos de la esposa tienen como padre al marido. Es una presunción legal. El Juez realiza una operación deductiva: si hay presunción debe tenerse por probado.

Las presunciones legales pueden ser juris et de jure y juris tantum. Es necesario distinguir la fuerza probatoria de cada una de estas clases de presunciones. Las primeras son aquellas que no admiten prueba en contrario. Tal la del Art. 313 del C.C.: cuando se reúne en favor de la filiación legitima la posesión de estado y el título, no puéde probarse contra la legitimidad del hijo. Las segundas son aquellas que admiten la prueban en contrario como las de los Art. $7 \circ, 173,185,187,202,221,299,300,455,498,807,828,910,911,912$. $1210,1241,1245,1246,1267,1282,1303,1226,1333,1367,1348,1393$, 1496, 1512, 1532, 1578, 1611, 1631, 1635, 1676, y 1754 del C. C.

Las presunciones legales tienen que estar expresamente establecidas en la ley, asi como su calidad. Por esto es que se presentan estos tres casos: a) Si indica que se trata de presunción que no admite expresamente prueba en contra, no hay dificultad y la prueba resultaria inadmisible; asi probar contra la cosa juzgada. b) Si dice la ley que la presunción admite prueba, quien alegue el hecho presumido no tiene que probar sino el antecedente en que se funda, la carga de la prueba gravita sobre la otra parte aunque sea la demandada. Asi el Art. $6^{\circ}$ del C. C.- c) Si no dice si admite prueba en contra, hay que concluir que se trata de sólo presunción juris tantum, porque las presunciones legales jure et de jure como leyes excepcionales deben ser expresas.

b. - Las presunciones simples o judiciales son aquellas que partiendo de un hecho conocido llegan al conocimiento de un hecho desconocido por la relación que hay entre ambos. Los indicios ${ }^{2}$ son los hechos conocidos que permiten mediante la concatenación entre ellos legar al conocimiento de un hecho desconocido. La presunción simple parte del indicio.- El Juez realiza estas operaciones al sentenciar.

E1 Art. 337, sólo se' refiere a las presunciones legales, son únicamente ellas las que no requieren ser probadas. Las que producen una reversión de la prueba, serán estudiadas al tratar de la cuestion de la carga de la obligación de probar.

5) Deben probarse los hechos que constituyen costumbres.- Art. 341. Para precisar el sentido de la regla de que la costumbre debe probarse que consagra este precepto de nuestro Código Procesal es conveniente distinguir la costumbre de los hechos notorios, de los hechos normales, y de los hechos evidentes.- a) Los hechos notorios son aquellos acontecimientos que el Juez por su versación no puede desconocer en un momento y lugar determinados. Por lo tanto forma parte del conocimiento privado del Juez. Se distingue del rumor público porque este no es un hecho comprobado.

1 Couture. Ob. cit. pág. 141. 
sino más bien un juicio o apreciación pública. Sólo los acontecimientos que constan de notoriedad ante el Juez, como sentencia que ha expedido en otro juicio, etc, no necesitan acreditarse. Pero no constituye una costumbre qus es una conducta generalmente admitida. b) Los hechos normales están constituidos por una conducta standard, una conducta generalmente segui. da por los hombres. La teoria del standard juridico, se diferencia de la costumbre en cuanto, el standard se aplica comio supuesto a una conducta determinada y personal y en cambio la costumbre es una conducta efectiva y colectiva. c) Los hechos evidentes constituyen lo que se conocen como la prueba prima facie, esto es aquel hecho cuya efectividad, como la obscuridad de la noche, no necesita demostración.

Nuestra legislación procesal a diferencia de legislaciones más moder. nas ${ }^{1}$ : no se refiere por lo demás expresamente, sino a la costumbre.

III. - Carga de la prueba. - Después de tratar del objeto de la prueba o sea de lo que debe probarse en juicio, exponemos, quienes deben probar, sobre quien radica la obligatoriedad o carga de la prueba.

Podemos exponer las reglas respecto a las partes y al Juez.

A) Respecto a las partes la regla es la del 337, según la cual las partes deben probar los hechos que aleguen. Esta regla constituye un aforismo en derecho procesal. Ya lo hemos justificado: el Juez no decide entre las simples y contrapuestas afirmaciones de las partes, ni según su propio entender, sino conforme a los hechos acreditados en el juicio.

Como consecuencia de este principio; 1) El demandante debe probar su acción esto es su afirmación, en todos los casos de contradicción, sea que el demandado haya simplemente negado los hechos sin afirmar otros, sea que haya opuesto otros hechos o no haya contestado la demanda en ninguna forma.

Sin embargo es conveniente tener en consideración las reglas sobre distribución de la prueba según los hechos expuestos, conforme a la clasificación de los profesores Alsina y Couture ${ }^{2}$ a) Hechos constitutivos, la prueba dé los mismos corresponde al actor que persigue el reconocimiento del derecho; asi el actor que cobra arriendos debe probar la existencia del con trato de locación, la calidad de arrendatario del demandado, b) La prueba del hecho extintivo, corresponde al demandado. Asi si en el caso propues. to como ejemplo, el arrendatario sostiene que ha abonado los arriendos que se cobran, o que es propietario del bien. c) El hecho madificativo o impeditivo puede corresponder al actor (si se trata de una acción declarativa, como en la prescripción adquisitiva que ha venıdo a modificar el dominio) - al demandado así como cuando se trata de una suspensión o no vencimiento del término de la obligación, de una excepción de pago, o en general de la alegación de un hecho extintivo de las obligaciones que se exigen al demandado. Por esto hemos dicho que el demandado no tiene que probar

1 Códigos de Alemania (Art. 291), Austria (Art. 269), Brasil (Art. 211), Italia (Art. 115), Méjico (Art. 88).

2 Alsina.- Ob. cit. T. II. pág. 192. Couture.- Fundamentos, pág. 150. 
sino las excepciones ${ }^{1}$. d) El hecho simplemente negativo, no puede probarse. Sin embargo es de notarse que las proposiciones negativas pueden encerrar una afirmación; asi el demandado al afirmar que no debe el crédito cuya existencia admite, está sosteniendo que ha pagado.

Pero el actor no tiene que probar, según la segunda parte del Art. 337. los hechos que se presumen conforme a ley, sequin ya se ha expuesto.

2) El demandado no tiene que probar sino en el caso de que se excepcione. Por esto es que la fórmula exacta, es que el que alega un hecho debe probarlo ya sea actor o demandado ${ }^{2}$.

B) Respecto al Juez.- El Juez no puede solicitar la actuación de r.rue. bas sino en forma restrictiva como consecuencia del sistema dispositivo que impera en nuestra legislación civil.

Sus facuitades al respecto están en el Art. 340. Las pruebas cuya actuación se decreta por propia iniciativa del Juez, se denominan pruebas de oficio.

El precento legal citado dispone que éstas se sujetan a los siguienteg reglas: 1) La ley las autoriza, desde que se dice que los jueces pueden decretarlas. Esto está justificado aún dentro del sistema dispositivo, desde que si el Juez cree necesario tales probanzas para formar su criterio, no puede negársele la facultad de procurárselas. Además es una concesión al sistema inquisitivo.

Los jueces tienen que ser muy cautos al hacer uso de esta facultad para que por su ejercicio no se subsane la omisión o error, en que haya incurrido una parte en el ofrecimiento o actuación de sus pruebas, mejorando con esta su situación dentro del proceso.

2) No están sujetas al término probatorio, pues se dispone que pueden decretarse en cual,juier estado del juicio.

3) No pueden decretarse de oficin, ciertas probanzas: la de testigos y juramento decisorio. Las razones, sín duda por dificultades prácticas o por la trascendencia de esta última, fundada en la solvencia moral que una parte atribuye a la otra. Menos explicación puede tener la prohíbición de ofrecer prueba testimonial's desde que puede constituír, como dentro de los procesos penales, investigación importante. Sólo puede admitirse por razón del descrédito de este medio probatorio, por fundarse igualmente en el fé que el testigo produce a quien lo ofrece, y por la dificultad práctica para conocer a las personas que pueden saber los hechos que se debaten generalmente en los procesos civiles.

4) El auto por el que se ordena una prueba de oficio es inapelable Indudablemente que esta disposición se funda en que no se puede ni pos acuerdo o simple coincidencia entre las partes, negársele al Juzgado los elementos que considera necesarios para formar su criterio sobre la cuestión

\footnotetext{
Alsina. - Ob. cit. T. II. pág. 192.

Couture. - Ob. cit. pág. 153.

Romero. - Ob. cit. T. II. pág. 266.
} 
propuesta. Asi tampoco el criterio del superior no puede impedirle que se procure el elemento de convicción que necesita. Por esto es que se justifica que ni siquiera se otorgue la alzada en un sólo efecto. Se ha criticado por el Dr. J. G. Roméro, que la ley sea tan absoluta, pero es que la denegatoria de la alzada o de, cualquier otro recurso no se funda en el propósito de evitar dilaciones, sino en que no se puede negar al Juez los eleméntos de convicción que reclama para su decisión.

Sanción. - Art. 338. - Por último la carga de la prueba como hemos visto, se impone por la ley y la doctrina, pero además la impone el interés de las partes, pues si quien está obligado a probar no lo hace, su pretensión será desestimada desde que el Juez sólo procede en vista de la comproba. ción de las afirmaciones.

El Art. 338 contiene esta sanción expresando que, si el demandante no prueba su acción será absuelto el démandado. Pero debe entenderse con un sentido más amplio y con las aclaraciones que anteceden y que se pue den sintetizar así: será absuelto el demandado si el actor no prueba los fundamentos de su acción cuando deba probarlos por no fundar su demanda en presunciones legales, o cuando el demandado no ha contradicho la acción invocando únicamente hechos extintivos de la obligación demandada.

IV TERMINO PROBATORIO.- La otra cuestión para exponer es el plazo dentro del cual se deben ofrecer y actuar las probanzas sabiendo que la ley debe fijar y fija los términos para ejercitar los actos procesales, tratamos ahora del término probatorio que es el plazo dentro del cual la ley permite ofrecer las probanzas y actuarlas. En el juicio ordinario este término es de diez dias prorrogables a 50 según el Art. 348 del C. P. C.

En cuanto a su cómputo el término probatorio es común. Por su calidad es prorrogable y por sus efectos, perentorio. Existe un plazo ordinario de prueba que puede emplearse mediante la prórroga al máximun, el plazo suplementario del Art. 351 y el plazo extraordinario constituido por el término de la distancia.

La ley distingue estos dos periodos.-1) el de ofrecimiento para presentar las pruebas dentro del cual pueden también actuarse; y 2) el de actuación únicamente para que se actúen las que estuviesen pendientes. Pero hay también pruebas privilegiadas que pueden ofrecerse y actuarse en cualquier momento. Procuraremos estudiar separadamente uno y otro periodo $y$ luego las pruebas privilegiadas colocadas fuera de todo tiempo.

1) Plazo de ofrecimiento de las probanzas. - Art. 349, 350 y 351.Distinguiendo los casos del término ordinario y del prorrogado en caso de que al término sea sólo de diez dias, este es un término a la vez de ofre. cimiento $y$ de actuación. Es natural que si un litigante ofrece su prueba al expirar el término ordinario, solicite prórroga del mismo para poder actuar sus probanzas.

En el caso de prórroga del término probatorio, el plazo de ofrecimien. to de pruebas es el de los 20 primeros dias del mismo. Art. 349. 
Debemos de notar que este periodo no es exclusivamente de ofrecimiento sino también de actuación de probanzas; pues el Art. 351 establece que las pruebas admitidas deben actuarse dentro del término probatorio y como forma parte de este el periodo de ofrecimiento, también dentro de él pueden ser actuadas las probanzas ofrecidas.

Sin embargo hay una excepción y es la del Art. 350 . Admitida la prue. ba que ofrezca una parte dentro de los 20 días y notificada su admisión después de este término, puede la parte a quien perjudica ofrecer la que le convenga, dentro del plazo de tres dias siguientes al de la notificación del decreto que admite dicha prueba.

Esta excepción se explica y justifica porque bastaría a una parte ofrecer su prueba el vigésimo dia para evitar que el contrario pudiera rebatirla mediante otras pruebas.

2.- Término de actuación de pruebas.- Arts. 351 y 352.- Este es el periodo dentro del cual las pruebas ofrecidas en tiempo hábil y pendien. tes, deben ser actuadas. Se dice pendientes porque dichas probanzas pudieron actuarse dentro de la etapa anterior. Es por lo tanto un término exclusivo para actuar las probanzas. Asi aparece del Art. 351 al prescribir que las pruebas deben actuarse dentro del probatorio. Por lo tanto tiene como duración los dias restantes del término probatorio después del periodo del ofrecimiento de pruebas, esto es 30 dias.

Pero hay excepciones a estas reglas y son las establecidas para los siguientes casos:

1) Las pruebas no actuadas por impedimento que la parte no ha po dido remover. Art. 351, segunda parte.

Es el caso del testigo reacio o de la inspección ocular no practicada por recargadas labores del Juzgado, étc. En estas circunstancias se puede solicitar un plazo extraordinario para la actuación de estas pruebas.

La concesión de este término extraordinario está sujeto a las siguientes reglas: a) Debe solicitarse dentro del probatorio o a lo más dentro del segundo dia después de su vencimiento. b) Debe tratarse de actuación de pruebas ofrecidas oportunamente y no actuadas por impedimento que la parte interesada no ha podido remover o evitar. Es claro que si no ha hecho uso oportunamente de los apremios legales para hacer concurrir a un testigo, no procederia solicitar plazo extaordinario para la actuación de esta probanza desde que la parte interesada ha podido procurar la actuación de este testimonio. c) Este término no excederá de 10 días. Asi resulta un plazo suplementario de actuación que puede permitir que este sea de 40 dias. d) No puede concederse sino una vez.

2) Las pruebas no actuadas dentro del término por oposición se podrán actuar dentro del plazo especial, que el Juez señalará al efecto. Seria, fácil burlar el derecho y la obligación de probar, mediante oposición cuya tramitación diera ocasión a que se venciera el término probatorio. Se burlaria también con esta maniobra la decisión judicial que declara infundada la 
oposición y procedente la prueba. Este precepto legal impide tales peligros, pues en este caso las pruebas pueden actuarse una vez resuelta la oposición.

Pruebas privilegiadas.- Son aquellas que por su especial importancia la ley permite ofrecer y actuar en cualquier momento del juicio Dentzo de nuestra legislación y en el juicio ordinario no tienen este carácter sino la confesión, Art. 364; el juramento decisorio, Art. 381, y la prueba instrumental en sus diversos aspectos, Arts. 409, 413, 434 y 441. Dentro de los incidentes sólo la prueba instrumental (Art. 206). En el juicio sumario admite la jurisprudencia la prueba instrumental en cualquier momento pero no hay ninguna prueba que tenga la calidad de privilegiada pues toda ella debe ofrecerse en el comparendo o dentro de los tres días posteriores a esta diligencia y actuarse. en los dias restantes del término probatorio que es de 10 dias prorrogables (Arts. 339, 942).

Término de la distancia. - Además de los términos ordinarios de actuación de pruebas existe el término extraordinario de la distancia.

Tiene por objeto dar mayor tiempo para la actuación de estas pruebas por la razones expuestas al tratar de los térmiros.

Se computa añadiendo al término ordinario el plazo fijado para el dt la distancia. Art. 359, según la Tabla vigente.

Las reglas a que está sujeta la concesión del término de la distancia son éstas: 1) Sólo procede cuando debe actuarse una prueba fuera del lu. gar del juicio. Art. 353. Esto no impide sin embargo que se actúen sin la concesión del término de la distancia, pues según el Art. 360, es una facultad y no una imposición de la ley.

2) El lugar donde debe actuarse la prueba debe distar más de 15 kilómetros, de aquél en que se sigue el juicio. Art. 353. Es una distancia prudencial, que hoy resulta muy corta. Nada justificaria que se concediera un término extrarodinario para estos casos, pues fácilmente puede trasladarse el Juzgado al lugar donde hay que actuar la prueba, empleando sin duda menos tiempo del que señala la tabla.

3) La concesión del término de la distancia debe pedirse dentro de los primeros cinco dias del término probatorio. Art. 353 .

4) La concesión del término de la distancia se pedirá en escrito que tẹnga según el Art. 354: a) la designación de la prueba, - b) del lugar donde' debe actuarse. - c) de los requisitos que la ley exige para que se actúe la prueba. Esto es si se trata de' una confesión, el interrogatorio; de un reconocimiento, al respectivo documento.

5) La solicitud de concesión del término tiene cierta tramitación. Art 355: a) Se corre traslado por un día, b) Se ordena en el mismo decreto que el solicitante empoce de veinte a cien soles si la prueba debe actuarse dentro de la República y, de cuarenta a doscientos soles oro si debe actuarse en el exterior. Esta consignación sirve para cubrir los perjuicios que se irrogue al contrario con la obtención del término de la distancia; c) Si el juez resuelve favorablemente se formaliza la consignación. Art. 356; d) Formalizada la 
consignación se libra exhorto. Art. 356; c) La parte contra la que se ofrece la prueba y para ejercer su derecho de presenciarla, puede designar una persona o simplemente señalar domicilio en el lugar donde debe actuarse la probanza, en un recurso que debe insertarse en el respectivo exhorto y para que se le hagan las respectivas citaciones.

6) La solicitud del término de la distancia puede dar lugar a sanciones. Estas sanciones son de dos clases: 1) Pago de los gastos en que incurriera el contrario para controlar la actuación de la prueba, Art. 357. Estos en dos casos distintos: a) Cuando la parte que ha solicitado el têrmino de la distancia no gestiona la actuación de la prueba. Parece ser el libramiento y diligenciamiento del exhorto. b) Si la prueba se actúa pero résulta impertinente. $\mathrm{La}$ impertinencia es claro que debe determinarse antes de admitirse la probanza y por lo mismo no puede aparecer de su actuación ${ }^{30}$. Pero es que la pertinencia de la prueba a veces puede apreciarse o decidirse con su simple ofrecimiento, pero otras veces no. Asi una prueba de confesión o de testigos cuyos interrogatorios no sé conocen al proponerse la prueba, serán admitidas como pertinentes, pero las diligencias pueden resultar inútiles y ociosas porque las preguntas que se formulan, por no tener relación con lo controvertido, resultan impertinentes. Es sin duda a este caso al que se refiere la regla que estudiamos.

El pago de estos gastos están sujetos a las siguientes reglas: 1) Se hace después de expedida la sentencia, Art. 357, segunda parte. Más estrictamente se decide sobre el particular en la sentencia a pedido de la parte perjudicada. 2) El Juez puede exonerar de este pago si se acredita que la prueba no se actuó por motivos justificados. Esto es si comprobara que no se habia producido el supuesto de hecho de la ley.

2) Multa.- Art. 358.- Se impone en los casos: a) de no haberse hecho diligencia alguna para actuar la prueba. Se refiere al caso de que librado el exhorto no se diligenció debidamente o no se procuró que surtiera efectos por los medios legales respectivos; b) de no haber tenido los testigos conociento de los hechos ni haberse hallado en condición de conocerlos. Lo que estaria acreditando el hecho de que con el ofrecimiento de tales testimonios sólo se procuró obtener la dilación del procedimiento mediante la obtención del término de la distancia; c) haber no existido los testigos o documentos en el lugar designado.

Las reglas a que se sujeta la imposición de esta sanción son las siguientes: 1) Se impone en la sentencia como resultado de que es en ella que se aprecia la prueba ofrecida. 2) Tiene un monto fijo; es igual al de las costas y gastos decretados en beneficio del colitigante. Asi resulta, por lo menos del texto de la ley, que quien recurre a la maniobra de obtener el término de la distancia maliciosamente, tiene la triple sanción del pago de costas del juicio, de los gastos ocasionados para controlar la prueba y de una multa.-

1 Romero. - Ob. cit. T. II. pág. 293. 
Indudablemente que las costas del juicio y los gastos del colitigante vienen a ser los mismos. Por último habria que dilucidar si es procedente el pago de tales gastos y de la multa en el caso de que la parte que solicitó el término hubiera ganado el pleito o por lo menos no hubiese sido conderado en costas. Siendo conceptos distintos al de costas, lo que se establezca definitivamente respecto a estas no debe afectarlas.

\section{IV - MEDIOS PROBATORIOS}

En el examen de esta materia debemos tratar de cómo se deben probar o demostrar los hechos controvertidos, los medios de los que las partes deben valerse para cumplir con la obligación que les impone las reglas sobre prueba que estamos exponiendo y la forma de emplearlos.

En primer lugar concretaremos la éxposición a los requisitos que deben reunir los medios probatorios; su clasificación y su valor en juicio distinto a aquel en que se actuaron.

Las condiciones de los medios probatorios son estas: 1) La legalidad (Art. 347).- Consiste en que el medio debe estar admitido como tal en la ley. Sin entrar a las cuestiones doctrinarias sobre el particular ${ }^{1}$, para determinar si es más conveniente el sistema de ja libertad o el de la legalidad, que indudablemente dá mayor seguridad y firmeza a los derechos, nos limitamos a indicar que nuestro sistema es el de la legalidad y no puede una parte servirse de distintos medios probatorios de los que la ley señala en el Art. 347, esto es la confesión, el juramento decisorio, inspección ocular, instrumentos, testigos y peritos. - En todo caso los nuevos medios técnicos que pudieran emplearse tienen que asimilarse a estos medios como las versiones fonoeléctricas o el examen hematológico.

2) La oportunidad. - No basta emplear uno de los medios que la ley franquea sino que es preciso que se haga oportunamente, esto es dentro de los plazos que la ley señala y que hemos expuesto con anterioridad. -

3) La publicidad.- Las pruebas deben hacerse valer dentro del término pero además con citación de la parte contra la que se ofrecen. Mientras no se reúne este requisito la prueba a pesar de ser legal y oportuna, no surte efecto ni tiene validez. - En virtud de esta citación la parte contra la que se ofrece puede ejercitar varias facultades, entre ellas la facultad general de oponerse a la admisión de la probanza y las facultades especia. les, que dependen de la naturaleza del medio probatorio y de su forma de actuación. Asi mientras que tratándose de la prueba instrumental la cita ción es para que aquel contra el que se ofrece, la acepte, la rechace o la contradiga, tachándola, etc., tratăndose de las pruebas no preconstituidas, como declaraciones testimoniales, confesión, inspección ocular, etc., la parte debe ser citada para la actuación de la misma, a fin de que la controle e intervenga en ella según las facultades que en cada caso le conceda la ley. Este

1 De la Plaza. - Der. Procesal. T. II. pág. 425. 
requisito obliga a que exista un plazo entre la admisión y la actuación de las pruebas simples o no preconstituidas.

Las reglas al respecto quedan reducicias a estas: a) Debe designarse día y hora para su actuación. (Art. 343). - Cuando se' trate de pruebas simples esto es no preconstituídas, que deben actuarse dentro del proceso, se debe señalar día y hora para que se actúen con citación de la contraria.- b) Debe médiar un plazo entre la admisión y la actuación de la prueba (Art. 344).El plazo que debe mediar entre la notificación del decreto que señala día para la prueba y la actuación de ésta es cuando menos de un día útil. Este plazo que media entre el decreto que admite la prueba testifical y el examen contra la que se ofrece la probanza, pueda preparar su contradicción y dis. poner lo conveniente a su defensa. Este plazo es mayor tratándose de prue. ba de testigos.- El Art. 468, establece que no puede ser menor de dos dias, el plazo que media entre el decreto que admite la prueba testifical y el examen de los testigos. Mayor plazo que se explica y justifica desde que puede ser necesario indagar la identidad de las personas propuestas como testigos y además calidades, para ejercitar los derechos de oposición o de tacha, que se estudiarán en su lugar.- c) Las partes pueden concurir a la actuación de las pruebas (Art. 345).- Pueden ejercer este derecho por sí mismas, por sus apoderados y abogados. Las facultades que entonces pueden ejercitar varian según el medio probatorio de que se trate y se determinarán al exponerse la forma de actuación de cada uno de estos medios probatorios.

4) Pertinencia.- Este requisito de los medios probatorios a emplear se ha analizado al tratar del objeto de la prueba.

Clasificación de los medios p robatorios: 1) Por la época de formación se clasifican en: a) preconstituídas o sea los que se han formado antes del juicio, tal los instrumentos en que los interesados hacen constar los diversos hechos, obligaciones y contratos que constituyen la prueba instrumental.- b) simples o circunstanciales, esto es constituidas dentro del juicio, tal la prueba testifical. La diferencia sustancial entre una $\mathfrak{u}$ otra no está en la forma escrita sino en que la primera contiene el hecho que se trata de acreditar; y la segunda la relación de tal hecho.-2) Por la clase de juicios en: a) ordinarios o voluntarios los que pueden emplearse en to. dos los juicios; y b) extraordinarios u obligatorios que necesariamente deben emplearse en determinados juicios, asi la irspección ocular en el juicio de deslinde. También pueden utilizarse los demás medios probatorios, pero sin prescindirse de aquellos.- 3) Por la forma de actuarse: a) directos o de evidencia inmediata, en los que el Juez constata por si los hechos, como en la inspección ocular; y b) indirectos, en los que la convicción se lleva al Juez por medio de un procedimiento deductivo, como sucede con las pruebas testifical y pericial.-- 4) Por el grado de convicción que producen: a) plenos, que producen certeza legal y por lo mismo que obligan la deci-

1 Alsina. - Ob. cit. pág. 177. 
sión del Juez; y b) semi-plenos, que el juez aprecia conforme a las reglas de la critica.- En nuestra legislación tienen carácter de pruebas plenas la confesión, el juramento decisorio, la prueba instrumental y la inspección ocular; los demás medios probatorios, sólo tienen fuerza semi-plena.

Así pues prescindiendo del examen de las contrapuestas razones respecto a los sistemas de la prueba libre y la prueba tasada, nuestra legislación ha adoptado un sistema intermedio, dejando que algunas probanzas sean libremente apreciadas por el Juez.

Los medios probatorios actuados en un juicio conservan su valor en otro (Art. 342).- No tienen carácter exclusivo los medios probatorios, para el juicio en que se han actuado, pueden hacerse valer en otro juicio con estas condiciones: 1) En cuanto a las personas, que el juicio o diligencia preparatoria en que se actuó y el juicio en que se quiere hacer valer se sigan entre las mismas personas o las que de ellas derivan sus derechos. Este principio es claro por razón del principio de contradicción de que hemos tratado. 2) Que no se trate de la prueba de testigos. La regla se funda en que la comprobación por medio de testigos requiere los esclarecimientos que propone cada juicio en particular y podría suceder que no se hubiese hecho las aclaraciones convenientes para que las respuestas sirviesen para un juicio distinto, aunque fuese entre las mismas partes. Ni siquiera seria posible admitirlo en los casos de muerte o ausencia del téstigo ${ }^{1}$ desde que las razones en contra son las mismas.

Debe tenerse en consideracion respecto a la regla que estudiamos la Ley número 4494 de enero de 1922, que prohibe ofrecer en prueba expedientes en giro, prueba que debe actuarse por medio de las respectivas copias certificadas.

Por último, es interesante el problema referente al valor de la prueba actuada en otro juicio. Parece que si la prueba ha servido para fundar un fallo que ha pasado a la condición de cosa juzgada, dicha probanza cualquiera que sea, ha adquirido el valor de prueba plena. Sin embargo no es asi. La sentencia podrá tener ese valor pero no la pruebas actuadas. Dificilmente podrian tener el mismo mérito y resultado tratándose de dos cuestiones juridicas distintas, que es el supuesto, pues de ser iguales, no cabria el segundo juicio. Además las pruebas se deben apreciar en conjunto con otras, que pudieran no haberse actuado, en el iuicio anterior.

\section{CONFESION.}

Definición.- La confesión es el medio probatorio que consiste en la declaración jurada que hace un litigante, a pedido del contrario, sobre los hechos controvertidos.

En esta definición hay que destacar lo siguiente: 1) Es una declara. ción jurada.- Esto es que es distinta del allanamiento que no es jurado y

1 Romero. - Ob. cit. pág. 279. 
también de las declaraciones que pueden hacerse simplemente por medio de los recursos que se presentan durante el proceso, las que no tienen la trascendencia de una confesión.

2) Es una declaración de parte.- En esto se distingue de la prueba testifical que es la declaración hecha por un tercero, o sea por quien no es parte en el juicio. De acá se deducen caracteres propios dé la confesión: a) se refiere a hechos propios del confesante, mientras que la declaración de testigos puede referirse a hechos de otro.- b) prueba contra el que ta presta; lo que no sucede con la prueba testifical que no afecta al propio testigo sino que puede tener trascendencia jurídica respecto de las partes.c) constituye prueba piena lo que no es la prueba testimonial.

3) Sobre los hechos controvertidos- Esto es que la confesión no sólo no versa sobre el derecho, porque esto sucéde con todo medio probatorio ${ }^{1}$, sino que no puede referirse a apreciaciones y juicios sobre los mismos hechos. Estos hechos por supuesto tienen efectos juridicos.

Las definiciones que la señalan como "testimonio de parte contra si misma" (Bonnier, Martirolo) o "testimonio de una parte cuando narra un hecho contrario a su propio interés" (Carnelutti) se refieren más bien a los casos en que hay una declaración expresa, no estrictamente a los de confesión ficta o tácita.

Elementos esenciales de la confesión; son: 1) Capacidad en el confe. sante (Arts. 367 y 368).-Dada la finalidad y ias consecuencias de la con. fesión se requiere la capacidad necesaria para obligarse. Es por esto que hay que establecer las siguientes reglas: a) pueden prestar confesión los que pueden comparecer en juicio por sí mismos (Art. 367); b) los que litigan a nombre o en representación de eatidades jurídicas, tienen la facultad de prestar confesión dentro de los límites de sus respectivas representacio. nes, para obligar y disponer de sus bienes (Art. 368). El apoderado, sólo que tenga poder especial para presentai confesión y si lo admite quien solicitó la prueba, pues por ser diligencia personal puede exigir que sea la misma parte quien la preste. Debe cuidarse de pedir la confesión personal para que no se entienda que puede prestarla el apoderado con poder sufi. ciente (Art. 369).- Los representantes legales de menores e incapaces, sólo pueden prestarla dentro de los limites en que pueden obligar a sus representados (Art. 368). La mujer casada (Art. 368, segunda parte) puede pres. tar confesión en los casos en que puede comparecer en juicio según los Arts. 22,23 y 24 . Las facultades que le ha concedido el nuevo C. C., le permite hacerlo en los casos en que se trate de sus bienes propios. - Los gerentes, administradores, presidentes en representación de personas jurídicas de derecho privado tienen la facultad y la obligación de prestar confesión (Art. 4).

2) Espontaniedad - Esta condición de la confesión supone que el confesante la preste sin ninguna sugerencia ajena, aún sin valerse de apun.

1 Alsina. - Ob. cit, pág. 226. 
tes o escritos como se estudiará particularmente al tratarse de la actuación de este medio probatorio. Para garantizar este requisito el interrogatorio puede permanecer en secreto hasta el momento de actuarse la diligencia mediante su presentación en pliego cerrado o sólo en el momento de la actuación de la prueba.

3) Oportunidad (Art. 364).-- Es procedente ofrecer y actuar la confesión conforme a estas reglas: en Primera Instancia, en cualquier momento, de tal manera que no está sujeta a los plazos legales ni para ofrecerse, ni para actuarse; esto es que puede hacerse antes, dentro y después del término probatorio. Aunque el pleito se encuentre ya expedito para sentencia procede este medio probatorio. Sólo hay prescripción especial para que, siempre que se solicite fuera del término probatorio, ya sea antes o después de este, se actúe en cuerda separada, para que no se interrumpa. con este motivo, la prosecusión del juicio, el que inclusive puede por lo menos, según el texto de la ley, hasta ser resuelto antes de que se actúe la confesión solicitada. A pesar de autorizada opinión ${ }^{1}$ por la doctrina y aún por la simple redacción de nuestro Código no puede actuarse la confesión en Primera Instancia después del fallo. Estaria esto conforme con la doctrina, desde que la confesión es un medio probatorio y por lo mismo no tiene ninguna utilidad que se produzca después de la decisión del Juez.Distinguiendo entre los casos en que la sentencia queda ejecutoriada y es apelada: en el primer caso sería improcedente actuarla después de pronunciada la sentencia por lo expresado; en el segundo porque aunque es cierto que en Segunda Instancia cabe actuarla cuando se abre a prueba el juicio, en esta instancia como esto sólo procede aduciendo nuevos hechos o nuevas excepciones y si no se trata de estos casos, sería improcedente continuar el incidente de confesion para que este se actuara y elevarlo al Superior para que lo tenga presente al resolver la alzada. Pero además y sobre todo nuestro texto legal no lo admite.

La etapa de la Primera Instancia queda concluida con la sentencia que alli se expide y por lo mismo aunque el juicio continúe en razón de apelar ción, se ha producido por la expedición de la sentencia la preclusión que cierra definitivamente esta fase del pleito.

La confesión puede pedirse varias veces a diferencia de lo que sucede. en los otros medios probatorios (Art. 363). Esta facultad se suprime en el Antéproyecto de reforma formulado por la Comisión Cornejo. Las confesiones posteriores deben versar sobre los hechos no interrogados antes 0 para aclarar las respuestas anteriores.

Clases-Se clasifican las confesiones en: 1) Expresa y ficta, según que el confesante concurra a prestarla, acatando el mandato del Juzgado o que sea remiso a él, obligando a darlo por confeso ya sea por su inconcurrencia reiterada a pesar de haber sido apercibido o porque asistiendo se negara a confesar debidamente.- 2) Tácita, si implicitamente reconoce

1 Romero. - Ob. cit. T. II. pág. 313. 
como exacto el punto interrogado.- 3) Simple, si implícitamente reconoce sin dar explicaciones de su dicho; y calificada, si lo hace dando una explicación a favor o en contra.- Estas clasificaciones son importantes para decidir sobre la divisibilidad de la prueba.

Actuación de la confesión.- (Art. 370).- Tratando de señalar por etapas estas constan en parte de los Arts. 469 al 489, exceptuando los artículos $471,474,479,485$ y 486 y se pueden reducir a las siguientes:

1) La citación.- Ya sabemos que pueden hacerse personalmente a la parte o a su representante, según se haya pedido la diligencia. Si la confesión debe prestarla personalmente quien litiga por apoderado debe citár sele en su domicilio real. - A los agentes diplomáticos acreditados ante el Gobierno peruano sólo se les puede citar a prestar confesión o declaración por medio del Ministerio de Relaciones Extericres, enviándoles copia del interrogatorio y si voluntariamente consienten en prestarla (Art. 485).

2) Designación de día, hora y lugar.- Como se trata de prueba que debe practicarse ante el Juzgado, se señalará dia y hora para que se actúe conforme el Art. 343 del C. de P.C. Debe mediar lo menos un dia entre la citación y el día de la diligencia (Art. 344). - La citación debe hacerse para que se actúe en el local del Juzgado. Más esta regla general admite estas dos excepciones: a) por razón de dignidad de la persona que debe prestarla (Art. 484), por la cual el Presidente de la República, el Arzobispo y los Obispos en su diócesis declararán a su elección, en sus propios domicilios o en el local del Juzgado; b) por razones de enfermedad o ancianidad o cual. quier otro motivo que el juez encuentre justificado (Art. 483), se puede disponer que se actúe en el propio domicilio dél confesante. - En ambos casos el Juzgado por sí o por medio de un Juez comisionado se constituye en el lugar donde debe actuarse la diligencia pudiendo asistir la parte que solicitó la confesión.- También debe actuarse la confesión ante los agentes diplomáticos y consulares del Perú (Art. 377), según se expondrá después.

3) Presentación del interrogatorio.- (Art. 366).- La confesión requiere siempre para su actuación de la presentación de un pliego conteniendo las preguntas sobre las que debe versar. En esto se diferencia de la declaración testimonial, la que, como veremos más adelante puede actuarse sin pliego si está presente la parte que la pidió (Art. 467). La razón de esta diferencia se encuentra en la diversidad de apercibimiento para el confesante y para el testigo que no concurre a la citación. El apremio de tenerlo por confeso que se dicta contra el confesante hace necesaria la existencia previa de un pliego.

Este pliego puede ser de dos clases: abierto y cerrado, según se presente para que el confesante conozca previamente las preguntas o no las conozca por haberse presentado en sobre cerrado antes o sólo en el acto de la diligencia.- En el juicio ordinario puede hacerse uso de una $\mathfrak{u}$ otra clase de pliego, pero tratándose de la absolución de posiciones en diligencia preparatoria el pliego debe ser abierto adjuntado a la solicitud por la que se solicita 
esta diligencia. Este pliego puede ser presentado hasta el momento de la diligencia (Art. 371).

4) Enseguida tiene que considerarse dos posibilidades: A) que el confesante comparezca; y B) que no comparezca.

A) El confesante comparece. - En este caso todavia hay que distin. guir: a) el confesante comparece y no encuentra pliego que absolver (Art. 372). Entonces se asienta la correspondiente acta y no procede señalar nuevo dia para la confesión mientras no se cumpla con estas dos condiciones: 1) se presente el interrogatorio; esto es quz ya no existe la facultad de presentarlo en cualquier momento, hasta la comparecencia del confesante (Art. 371): y 2) abonando una multa que según el Art. 372 era de una a veinte libras y que la Ley 11363. Art. 3\%, ha aumentado a S/. 50.00.

b) El confesante comparece y encuentra el pliego en cuyo caso se actúa la diligencia en esta forma: 1) Se toma juramento al confesante (Art. 469). Esto lleva a la discusión que existe sobre la conveniencia de mantener el juramento. Se sostiene que es inútil por la frecuencia de los perjurios, lo cual seria una razón admitible. También que los ateos no podrán prestarlo dada la fórmula establecida y si lo hacen no tiene ningún valor ${ }^{1}$. Por otra parte se dice que constituye una presión moral para obligar a decir la verdad a personas dé conciencia. En este supuesto, no se requiere presión para que diga la verdad. Esto envuelve una cuestión de orden moral que no nos toca examinar por la naturaleza de nuestro estudio.- 2) La diligencia se puede actuar ante el actuario de la causa (Art. 470), siempre previo juramento ante el Juez, con tal que se cumpla con estas condiciones: a) que ambas partes estén presentes; b) que consientan en ello. Este precepto se ha establecido sin duda para facilitar la actuación de la prueba. Hoy seria realmente imposible que los jueces pudieran presenciar todas las confesiones y las declaraciones testimoniales que cada tarde se actúan en su Juzgado. Esto ha hecho que la prescripción excepcional que estudiamos se convierta en la regla, hoy è Juez no actúa en su presencia la confesión sino a pedido de las partes, y genéralmente después de haber tratado de disuadirlas de ello y poco dispuesto, no por otro motivo sino por sus múltiples atenciones.

3) Las preguntas. - Cada pregunta debe referirse a un hecho solo (Art. 475). Ya sabemos qua tinicamente se puede interrogar sobre hechos. Esta regla tiene por objeto que el confesante se pronuncie concreta y claramente. La infracción de esta regla no está sancionada. Por esto, sin duda, es diariamente desconocida y sólo obliga a contestar sobre cada una de las partes de la misma pregunta.

Estas debe ser pertinentes según el principio generai.- Cabe oposición a que se contesten si son impertinentes. El auto del Juzgado al respecto es apelable en doble efecto, la alzada formulada durante una confesión no suspende la diligencia, pero si la contestación a la pregunta y sólo se debe proveer al finat de la misma.

1 Romero. - Ob. cit. pág. 325. 
4) El confesante debe responder por si mismo de palabra sin valerse de apuntes y sin consejo de nadie, ni de su abogado. Es la expontaniedad de la hemos tratado anteriormente y tiene por objeto que la confesión surta el efecto de producirse conforme a la verdad de los hechos preguntados.Sin embargo hay una excepción (Art. 372), puede permitirsele que consulte libros de cuentas o papeles cuando sea necesario para precisar la respuesta.

Las respuestas debe ser afirmativas o negativas (Art. 473), pero esto no impide que el confesante añada todas las aclaraciones y explicaciones que crea convenientes. Estas pueden inclusive contener apreciaciones y juicios. El actuario va consignando en un acta ya sea textualmente o nó, las respuestas. Si el confesante es sordo-mudo que sabe leer y escribir, único caso en que podria comparecer, responde por escrito, escribiendo sus respuestas en presencia del Juez (Art. 481).

Puede también no conocer el confesante, el idioma castellano en cuyo caso deberá ser asistido por un intérprete que nombra el Juez y à cuyo nombramiento, aceptación del cargo y atribuciones se aplican las reglas de los peritos (Art. 480).

El confesante al responder puede colocarse en estas tres posiciones distintas: 1) contesta precisamente. En cuyo caso no hay ningún problema. El Juez puede pedirle en todo caso de imprecisión una aclaración de sus respuestas. - 2) evade la respuesta. El Juez debe ordenar que la precise, pudiendo inclusive hacer uso de las facultades de apercibirlo. (Art. 374), y si se mantiene en esta actitud haciendo efectivo el apercibimiento puede darlo por confeso, teniendo por absuelta la pregunta en sentido afirmativo.3) el confesante afirma que no recuerda. No cabe recurso alguno, salvo las repreguntas, para procurar demostrar la insinceridad del confesante.

5) Después de absueltas las preguntas del interrogatorio escrito, este puede ser ampliado formulándose verbalmente nuevas preguntas. Estas las puede hacer: a) Quien solicitó la confesión. Este derecho lo puede ejercitar por sí mismo, por su representante o por medio de su abogado (Art. 474) y asi este último puede hacerlo estando o nó presente en la diligencia su patrocinado. La ampliación no tiene que referirse necesariamente a los hechos que han sido materia de interrogatorio escrito, basta con que se refiera a los hechos controvertidos.- b) el Juez también puede formular preguntas al confesante por lo tanto en forma de ampliación del interrogatorio presentado por la parte solicitante de la confesión (Art. 370 y 477). Estas tienen la calidad de pruebas de oficio y por lo mismo no cabe contra ellas recurso alguno.

Las respuestas se dan verbalmente, salvo que el confesante sea sordomudo.

De todo lo actuado se extiende acta.

6) Termina la diligencia pero antes de cerrarse el acta que la contiene, preceden dos hechos: 1) el confesante deberá leer el acta o hacerla leer por el actuario (Art. 478).-2) el Juez preguntará al confesante (Art. 478) si sé ratifica en la confesión. El confesante puede optar por ratificarse en lo de- 
clarado, por añadir o variar lo que aparece declarado en cuanto no se conformà con lo que ha expresado.

7) Luego firman el acta el Juez, el confesante, la otra parte que ha intervenido en la diligencia ya sea personalmente o por medio de su abogado o apoderado y el actuario. Si el confesante no sabe firmar se hace constar en el acta esta circunstancia (Art. 378, segunda parte).

B) El confesante no concurre a prestar confesión. Este es el segundo supuesto (Art. 373).

En este caso si no concurre a la primera citación, se le deberá citar nuevamente bajo apercibimiento. $\mathrm{El}$ apercibimiento procedente es el de tenerlo por confeso, esto es por haber contestado afirmativamente a todas las preguntas del pliego de posiciones.

Esta sanción se establece porque el silencio puede tomarse como una manifestación de voluntad cuando existe obligación de responder. Para que proceda dicho apremio debe haberse presentado el pliego que contiene las posiciones bajo cualquiera de las dos formas, cerrado o abierto.

Si el confesante no concurre sin causa justificada a esta segunda citación, a pedido de parte, se hace efectivo el apremio. Para esto se procede a abrir el pliego si es cerrado, se rubrica por el Juez y se declaran absueltas en sentido afirmativo las preguntas que contiene. Sólo las preguntas propuestos en forma afirmativa pueden ser dadas por confesadas en forma también afirmativa (Art. 375), pero ellas tienen el mismo valor y eficacia que las absueltas expresamente.

Actuación de la confesión fuera del lugar del juicio- Completando las disposiciones sobre actuación de la prueba de confesión debemos tratar de las particularidades que esta ofrece cuando se actúa en lugar distinto del que se sigue el juicio. (Arts. 376 y 377). Para estos casos rigen las siguientes reglas especiales:

1) El interesado debe presentar el interrogatorio al solicitar que se libre exhorto por el que se comisiona a otro Juez que actúe la diligencia. (Art. 488). El pliego puede ser abierto o cerrado, pero es esta la oportunidad de presentarlo y no hasta el acto de la diligencia como es lo ordinario.

2) Puede designarse personero especial para esa diligencia.- Estimo que la designación de personas que represente a quien solicitó la confesión, sólo puede ser aplicable a los testigos, en cuanto a reemplazar en esta forma la presentación del pliego interrogatorio, desde que sólo las declaraciones testimoniales pueden actuarse mediante interrogatorio verbal, pero no la confesión que requiere pliego. La designación de personero para la confesión es para controlarla y aún ampliar el pliego en el lugar donde se actúa, no para sustituir la obligación de presentar previamente el interrogatorio.

3) La comisión puede recaer en otro Juez o en los agentes diplomáticos y consulares del Perú en el extranjéro. (Art. 377, primera parte).

4) Las facultades de dictar o hacer efectivos los apremios por resistencia a declarar o inconcurrencia depende del comisionado: a) si el comisionado es otro Juez, la comisión comprende la facultad de emplear los apre- 
mios legales hasta que las posiciones sean contestadas o se den por absueltas. Sin embargo estos no pueden decretarse de oficio sino a pedido de parte (Art. 376). Pero tratándose de jueces de paz no puede ser esto admisible. Hay cierta vacilación al respecto; b) si el comisionado es agente diplomático y consular del Perú en el extranjero (Art. 377) sólo tiene las facultades de actuar la confesión, citar al confesante por dos veces, y en caso de inasistencia del confesante dejar constancia de este hecho. Es el Juez de la causa el que hará efectivo el apercibimiento de darlo por confeso.

Eficacia o valor de la confesión. - Al respecto las reglas recogidas en nuestro C. de P.C. se puede sintetizar en las siguientes:

1) La confesión prueba contra el que presta (Art. 378).- Dentro de la naturaleza propia de esta probanza está que con ella se persigue que el que confiesa admita un hecho que le perjudica. En la práctica se observa a veces casos en que el confesante cree que si no expresa cuanto le favorece se perjudica, lo que no es exacto.

2) La confesión prueba plenamente (Art. 378) contra el que la presta.- La prueba plena es la que obliga la decisión del Juez. Pero no se puede admitir el principio en forma tan absoluta. Como la confesión equivale al reconocimiento de una obligación no tiene esta fuerza plena, capaz de arrastrar la decisión judicial en los casos: a) que los hechos admitidos sean contrarios al orden público o las buenas costumbres. Así por una confesión no podrá alterarse el régimen de la sociedad de gananciales que con el carácter de institución de orden público, establece nuestra ley; y b) cuando se prueba que está herida de algunos de los vicios de la voluntad, error, dolo o violencia ${ }^{1}$, lo que algunos autores no admiten.

3) La confesión conserva el valor indicado aunque se actúe ante Juez incompetente (Art. 379).- Lo cual no requiere análisis, pues la confesión no debe su valor y eficacia al Juez, sino al propio confesante, y a que se actúe con la expontaniedad requerida.

4) La confesión es indivisible (Art. 380), - -esto es que debe apreciar. se en conjunto. - Esta cuestión de la divisibilidad de la confesión ha dado motivo a encontradas opiniones y sistemas legislativos.

Este principio está a su vez regido por los siguientes supuestos: a) la confesión no puede dividirse en perjuicio del confesante; y b) no puede estarse a la favorable y no a lo adverso del mismo hecho.

Al principio de la indivisibilidad reconoce nuestra legislación dos excepciones: 1) Que la confesión contenga hechos diversos independientes unos de otros (Inc. 1c del Art. 380). Tratando de precisar este concepto, los hechos independientes son aquellos que no tienen relación unos con otros. Estos pueden provenir de la forma de préstar la confesión ${ }^{2}$. En la confesión calificada y en la confesión compleja hay hechos diversos. En la primera el confesante no se limita a contestar sino que añade al hecho reco-

1 Alsina. - Ob. cit. pág. 282.

2 Alsina. - Ob. cit. pág. 276. 
nocido una significación especial modificatoria, asi se reconoce que recibió la suma que se le cobra pero no en carácter de préstamo sino en pago de una deuda. En este caso la confesión es indivisible.

En la confesión compleja hay dos hechos también pero que pueden ser separadas, asi si el confesante afirma que recibió en préstamo el dinero pero añade que lo canceló; esto es, invoca contra su afirmación una excepción o causa extintiva de las consecuencias juridicas de hecho, la que debe probar. En este caso es divisible la confesión.

2) Cuando el colitigante demuestra la falsedad de parte de lo decla. rado (Inc. 2, Art. 380) - - $\mathrm{Si}$ por el colitigante debe entenderse, aunque impropiamente denominado, al contrario, y le interésa demostrar la falsedad de lo declarado por su contra parte, es porque esa declaración favorece al último, pero como la confesión no prueba a favor del que la presta, no tendrá mayor interés en hacerlo.

Sin embargo este punto se relaciona con la cuestión de la revocabilidad de la confesión. En principio la validez de los actos procesales depende de su forma y por lo mismo los vicios de la voluntad no le afectan. Pero se exceptúa entre otros (la transacción) el error de hecho en la confesión ${ }^{1}$ lo que está justificado desde que se supone en ella una voluntad conciente. El error no puede servir dé base a la justicia ${ }^{2}$. Este principio fue admitido en Roma y ha sido expresamente recogido en varios Códigos modernos, inclusive el nuestro en el artículo que comentamos.

Solamente dos aclaraciones al respecto: 1) la prueba con que se pretende obtener la revocatoria de la confesión tiene que ser de la misma jerarquia que esta última. Lo que equivale a afirmar que debe ser o prueba instrumental pública o con calidad de tal, o la confesión del contrario. Sólo asi podrá prestársele valor a la ley que por si misma tiene por concesión de la ley, mérito y valor de fé plena. 2) la solicitud de revocación de la confesión deberá tramitarse en cuerda separada, como incidente, y sólo se resolverá en la sentencia, al apreciar el juez, en conjunto, todas las probanzas actuadas.

\section{JURAMENTO DECISORIO}

Este medio probatorio consiste en la confesión prestada por una parte a pedido de la otra parte para que según su resultado, se decida la controversia.

De esta definición resulta que es una especie de la confesión, por lo que tiene que prestarse bajo juramento. La confesión puede ser indecisoria y decisoria. La primera, que es la que hemos estudiado anteriormente, tiene el carácter de prueba plena pero no decide la controversia, admite otras probanzas concomitantes y aún probar contra la confesión mediante medios probatorios del mismo mérito. La segunda, en cambio, es la confesión que decide el pleito y por lo mismo elimina la posibilidad aún de admitir otras

1 Prieto Castro. - Ob. cit. T. I. págs. 216 y 328.

2 Romero. $\sim$ Ob. cit. T. II. pág. 359. 
probanzas. Después del juramento decisorio, no cabe sino la expedición de la sentencia de conformidad con el juramento prestado.

Ambas están consideradas como medios de prueba independientes en nuestra legislación procesal.

Las similitudes entre la confesión indecisoria y decisoria, o sea entre la confesión y el juramento decisorio, según la denominación de nuestro Código está en que ambos son medios probatorios; a mbos son obligatorios, ésto es que no pueden eludirse por el confesante a quien se le solicite, sin incurrir en la muy severa sanción de darlo por confeso, y en que ambos se prestan bajo juramento de decir la verdad, en que son diligencias personales $y$ en fin porque solo puede ser materia de ellas aquello que puede ser objeto de transacción. Pero ambos medios de prueba se distinguen entre si:

1) porque mientras la confesión sólo vale en lo que le es desfavorable y adverso al confesante, en el juramento decisorio, también valen aquellos hechos que le favorecen;

2) por su distinta forma de actuación; y,

3) por el distinto valor de ambas probanzas, desde que sólo el juramento decisorio decide el juicio. Estrictamente mayor valor como medio de certeza lo tiene la confesión indecisoria, porque el confesante admite como cierto lo que le perjudica, que el juramento décisorio, en el que sólo hay una verdad legal, aunque incontrovertible, constituida por el reconocimiento de un hecho que puede ser favorable' el confesante.

Para la mejor determinación de la naturaleza del juramento decisorio es preciso distinguirlo también de la transacción y del allanamiento.

El juramento decisorio no es una transacción. Es verdad que se prescribe que no puede ser materia de juramento decisorio lo que no puede ser objeto de transacción según el C. C. y también es exacto que en el Derecho Romano el pretor Paulo, lo consideraba una forma de transacción ${ }^{2}$, pero la diferencia está sustancialmente en que mientras la transacción es un acto voluntario, el juramento decisorio es obligatorio; además se diferencian en sus formas y efectos.

Tampoco debe confundirse con el allanamiento. Existen entre ellos la similitud de que producidos uno y otro debe venir la sentencia. Pero tam. béin el allanamiento es voluntario, y el juramento decisorio no lo es. Además se distinguen en su forma de actuación y porque el allanamiento se refiere a los hechos y al derecho, mientras que el juramento decisorio sólo a los hechos controvertidos.

Importancia.- Para algunos tratadistas constituye la meior probanza; para otros es tan inútil que debe eliminarse de la legislación. Tan divergentes opiniones nacen de muy distintos enfoques de la cuestión. Sin duda que únicamente debe advertirse que se trata de un medio de prueba que debe usarse con el máximum de precauciones y cautelas, sólo en casos excepcionales.

1 Alsina. - Ob. cit. T. Il. pág. 506. 
Debe notarse que hay varias objeciones a considerarlo como la prueba más segura, pues como ya se ha expresado, carece de los supuestos para producir certeza absoluta, desde que el confésante puede mentir y produce certeza legal aún en el caso de evidente falsedad. Pero además se funda en el supuesto de veracidad y honorabilidad del confesante, que debe ser incapaz de negar la verdad, aunque en éllo vaya su perjuicio. Desgraciadamente hoy tales casos son tan reducidos, que la prueba ha perdido aplicación. Precisamente en ésto se funda la opinión de que debe eliminarse de la legislación. Hay que convenir en que si la persona a quien se pide el juramento turiera efectivamente las condiciones morales mencionadas, se habría allanado a la demanda y el juicio no existiria.

El Proyecto de Reforma del C. de P. C., no incluye el juramento decisorio entre los medios probatorios.

Pero posiblemente no se debe proceder en forma tan drástica. Sólo debe emplearse esta probanza en el caso de tener completa confianza en la calidad moral de la persona a quien se le solicita, caundo no hay otras pruebas que la eventual confesión del contrario, o cuando se está dispuesto a cualquier sacrificio antes de hacer público, mediante los medios ordinarios de pruebas, hechos bochornosos o denigrantes. En otros supuestos no debe emplearse esta prueba.

- Sus caracteres. - El juramento decisorio según lo expuesto tiene los siguientes caracteres.

1) es personal, en el sentido que ningún litigante puede negarse a prestarlo por sí aunque tenga apoderado. Sólo puede eludirlo defiriendo al del contrario. Además es personal porque estrictamente tiene que referirse a hechos propios del confesante. Esto no impide que se pueda prestar por apoderado con poder especial, si a ello consiente el solicitante.

2) es obligatorio, porque como se acaba de expresar no puede eludirse sino refiriéndolo al contrario. El omiso es dado por confeso.

3) es indivisible, como la confesión. Debiendo advertirse que el problema es menos común desde que la respuesta debe ser escueta.

4) es irrevocable, a diferencia de la confesión como se ha expuesto anteriormente, desde que no cabe la prueba en contrario.

5) es definitivo desde que por su sólo mérito se debe decidir la controversia.

Personas que pueden prestar juramento decisorio- - Arts. 384-386.Según el art. 384, sólo pueden pedir y prestar juramento decisorio, los que están facultados para prestar confesión; ésto es una remisión al art. 367 del C. de P. C., que expresa la regla general de que pueden prestar confesión los que pueden comparecer en juicio por si mismos.

Pero por el art. 386 existe la prohibición de ofrecerlo o de prestarlo a las personas que se indican en el art. 368 o sea a los representantes legales y a los mandatarios judiciales, ésto es "a los que por disposición de la ley o designación judicial representan intereses ajenos".- Sin embargo, respecto a estas últimas cabe aclarar que si además de las facultades de que goza 
según ley, arts. 3 y 27 , se les ha otorgado facultades especiales y entre ellas las de deferir o prestar juramento decisorio, no habria inconveniente legal para ello, aunque hay autorizada opinión en contra.

Corresponde a la teoria de las obligaciones examinar los efectos del juramento decisorio en los diversos casos de solidaridad, como lo hace claramente el Dr. J. Guillermo Romero.

Procedencia del juramento decisorio.- Art. 383.- Se trata de determinar lo que puede ser objeto de esta probanza. - El art. 383 establece que no puede ser materia del juramento decisorio los actos que exigen solemnidad, ni las materias sobre las que las partes no pueden transigir, ni sobre actos o contratos para cuya validez se exige en forma escrita. Todos ellos se justifican por si solos. Especialmente debe notarse en cuanto al último caso que no se trataria de prueba preconstituida, que es la que exigen ciertos actos como el mutuo mayor de $\mathrm{S} / .500$ y otros.

Actuación del juramento decisorio- - Se puede señalar por etapas:

1) oportunidad.- art. 381.

El juramento decisorio es prueba privilegiada y por lo mismo puede ofrecerse y actuarse en cualquier momento del juicio. Sin embargo es conveniente aclarar que no procede antes del juicio, en diligencia preparatoria. Tampoco procede en Segunda Instancia si no cuando se haya abierto el juicio a prueba, porque deben seguirse las normas generales desde que no existe ninguna excepción.

2) la solicitud debe reunir varios requisitos.- Art. 390.- a) adjuntar el interrogatorio en pliego abierto. A diferencia de la confesión no cabe optar entre el pliego cerrado y abierto, siempre tiene que ser pliego abierto para los efectos a que se contraen las reglas siguientes, especialmente su examen por el juez.- b) debe contener una suscinta relación de los hechos primordiales de que depende la decisión de la controversia.

3) el Juzgado manda poner la solicitud y el interrogatorio en conocimiento de la persona que debe prestar el juramento-- Art. 391.- Esto tiene por finalidad que el confesante acuda a prestarlo o pueda deferir al juramento del contrario y también hacer las observaciones que crea necesarias respecto al pliego para que el Juzgado las tenga presentes al ejercer la facultad de examinar y aprobar el interrogatorio. Este derecho lo debe ejercer dentro del segundo día de notificado.

4) El Juzgado decide sobre la admisibilidad de la prueba y en caso afirmativo examina el interrogatorio, aprueba o modifica el interrogatorio y señala día para la diligencia. Así vencido el término de los dos días el juez tiene que: a) pronunciarse sobre la procedencia o improcedencia de la prueba. Esto es, decidir sobre si está o no comprendida dentro de algunos de los casos en que por razón de la persona o de la materia está prohibido el juramento desisorio.- b) el juez en caso de aceptar la probanza examina el interrogatorio. Las facultades al respecto son amplias de tal manera que puede modificarlo o ampliarlo, siempre con el objetivo que sea lo más claro y preciso y que permita una respuesta categórica sobre los hechos de que 
depende la decisión del pleito.- La decisión del juez es inapelable en cuanto a las modificaciones que introduzca en el interrogatorio.- c) el juez señala dia y hora para la diligencia.

5) La parte a quien se ha pedido el juramento no puede eludir el prestarlo personalmente si asi lo exije el solicitante.- Art. 388. - Pero puede evitarlo defiriendo o refiriéndolo al juramento del contrario. - Art. 386. Este derecho tiene estas características: a) puede hacerlo hasta un dia antes del día señalado para la diligencia.- b) el contrario no puede, en este caso, negarse a prestarlo.- c) el que ha deferido el juramento del contrario puede desistirse de ello hasta antes que el contrario empiece a declarar. Art. 387.

6) La diligencia de absolución del pliego interrogatorio se practica como la confesión. - Art. 392 - y le son aplicables las disposiciones de los art. 373 y 374 , esto es que si el obligado no comparece a la primera citación se le volverá a citar bajo el apercibimiento de tenerlo por confeso y en el caso de nueva inconcurrencia, como cuando habiendo concurrido se negara a contestar, se le dará por confeso, aún de oficio, siendo esto último, de discutible justificación.

Fuerza probatoria - art. 393. - Ya se ha indicado que el juramento decisorio, no sólo tiene fuerza plena, sino decisiva para el pleito. Después de él, todas las demás probanzas son inútiles. El juez debe sentenciar necesariamente según el mérito que arroja el juramento decisorio.

\section{INSPECCION OCUILAR.}

Consiste en el medio probatorio por el que el juez constata personalmente los hechos materia de la controversia.

Por esto se le denominó también antiguamente, "inspección de ojos" por que mediante ella, el juez, que debe ser de preferencia el mismo de la causa, comprueba por sí los hechos sin recesidad de recurrir al testimonio de terceras personas, ni a los conocimientos de otras. Por lo dicho precisamente es que se diferencia de la prueba iestimonial y de la prueba pericial. De la primera por que no és la relación que se hace de tales hechos, sino que el juez constata por sí mismo los hechos. De la segunda por que tampoco es la apreciación indirecta hecha por peritos, sino la que hace el juez según su leal saber y entender. Esto no obsta para que se haya permitido, complementarla con una y otra, o con ambas de las citadas pruebas. Pero el mérito de la inspección ocular es pleno mientras que las pruebas testimonial y pericial se aprecian conforme a las reglas de la critica, no obligando necesariamente, la decisión del juez.

Importancia.- De lo expuesto sobre la inspección ocular y su eficacia probatoria plena se deduce su importancia. Sobre todo en los juicios en que se ventilan derechos sobre cosas o por razón de las cosas, esta probanza es decisiva; asi tratándose de interdictos de obras nuevas o ruinosa, servidumbres, etc. Pero resulta casi inaplicable o inútil en controversias sobre otros derechos. 
Actuación.- Arts. 394. 395, 398 y 399.- - La actuación de esta probanza se puede sintetizar asi: 1) Oportunidad. La inspección ocular no es prueba privi'egiada y por lo mismo debe ofrecerse y actuarse dentro del término ordinario de prueba. Puede ser también decretada de oficio en cuyo caso si procede en cualquier momento del juicio.

2) El Juez señala día y hora para la diligencia. Art. 394.- Es indudable que sería mejor indicar también el lugar donde debe llevarse a efecto la inspección y precisar el objeto de la misma. En el mismo decreto el juez establecərá: a) si practicará personalmente la diligencia. Ya el art. 394 impone esto siempre que haya de practicarse en el lugar del juicio o las circunstancias lo requieran. Siempre debe estimarse necesario que el juez ante quien se sigue la causa, practique personalmente la diligencia, teniéndose en consideración la finalidad de esta probanza, esto es la constatación personal y de visu de los hechos materia de la controversia. No se trata que el juez conozca por referencia de otro juez el estado de las cosas sobre el que debe decidir en su sentencia, si no que sea él mismo quien lo aprecie. Sćlo cuando esto paralizaria las funciones judiciales puede admitirse que la inspección ocular se actúe mediante comisión. Esto justifica la regla.- b) si la practica solo o asesorado por peritos.- art. 398. - Cuando se requieren conocimientos especiales, nó para constatar los hechos, si no para conocer la importancia o razones de ellos, cabe que el juez de oficio nombre uno o dos peritos que lo ilustren al respecto, en la inspección ocular. - La actuación de estos peritos se rije por las reglas de la prueba pericial.- c) admite o rechaza el pedido que se le haya hecho para que en el acto de la d.ligencia de inspección ocular se actúe prueba testimonial.- art. 399.- La ley faculta a las partes para solicitar que la prueba de testigos se actúe conjuntamente con la inspección ocular, si eillo puede servir para la mayor claridad del testimonio. Este caso se actúa según las reglas establecidas para la prueba testimonial.

3) La diligencia de inspección ocular se actúa dejándose en acta constancia de las comprobaciones que hace el juez.- art. 39. - Las partes pueden solicitar también que se hagan otras constataciones que estén dentro del objeto principal de la prueba. Pero las partes no deben hacer alegaciones. Estas no deben revestir la forma verbal, sino hacerse por escrito. El acta será suscrita por todos los intervinientes en la diligencia, inclusive los testigos que hayan declarado y los peritos, aunque estos puedan presentar su dictamen posteriormente, dentro del plazo que se les haya concedido para hacerlo.

4) Los gastos de la diligencia de inspección ocular son abonados por quien la solicita. Si ha sido decretada de oficio en todo, o en la parte de los peritos, sérán abonados respectivamente por partes iguales entre los litigantes.

Valor probatorio.- Art. 396. La inspección ocular constituye prueba plena respecto de los hechos constatados por el juez. 